\title{
Right ventricular infarction : its detection by electrocardiography and its effect on right ventricular ejection fraction
}

Citation for published version (APA):

Braat, S. H. J. G. (1984). Right ventricular infarction : its detection by electrocardiography and its effect on right ventricular ejection fraction. [Doctoral Thesis, Maastricht University]. Rijksuniversiteit Limburg. https://doi.org/10.26481/dis.19840906sb

Document status and date:

Published: 01/01/1984

DOI:

10.26481/dis.19840906sb

Document Version:

Publisher's PDF, also known as Version of record

Please check the document version of this publication:

- A submitted manuscript is the version of the article upon submission and before peer-review. There can be important differences between the submitted version and the official published version of record.

People interested in the research are advised to contact the author for the final version of the publication, or visit the DOI to the publisher's website.

- The final author version and the galley proof are versions of the publication after peer review.

- The final published version features the final layout of the paper including the volume, issue and page numbers.

Link to publication

\footnotetext{
General rights rights.

- You may freely distribute the URL identifying the publication in the public portal. please follow below link for the End User Agreement:

www.umlib.nl/taverne-license

Take down policy

If you believe that this document breaches copyright please contact us at:

repository@maastrichtuniversity.nl

providing details and we will investigate your claim.
}

Copyright and moral rights for the publications made accessible in the public portal are retained by the authors and/or other copyright owners and it is a condition of accessing publications that users recognise and abide by the legal requirements associated with these

- Users may download and print one copy of any publication from the public portal for the purpose of private study or research.

- You may not further distribute the material or use it for any profit-making activity or commercial gain

If the publication is distributed under the terms of Article $25 \mathrm{fa}$ of the Dutch Copyright Act, indicated by the "Taverne" license above, 
Right Ventricular Infarction

Its detection by electrocardiography and its effect on right ventricular ejection fraction. 
Maastricht, 1984

Druk: Leiter-Nypels bv 


\section{Right Ventricular Infarction}

Its detection by electrocardiography and its effect on right ventricular ejection fraction.

Proefschrift

Ter verkrijging van de graad van doctor in de Geneeskunde aan de Rijksuniversiteit Limburg te Maastricht, op gezag van de Rector Magnificus Prof.Dr. H.C. Hemker, volgens besluit van het College van Dekanen in het openbaar te verdedigen in de aula van de universiteit op 6 september 1984 des namiddags te vier uur.

door

Simon Hubertus Joseph Gerardus Braat, geboren te Roosendaal op 17 maart 1948. 
Promotor Prof.Dr. H.J.J. Wellens

Referenten Prof.Dr. J.A. Flendrig

Prof.Dr. F.L. Meyler

Prof.Dr. F.J.Th. Wackers

Het verschijnen van dit proefschrift werd mogelijk gemaakt door steun van de Nederlandse Hartstichting en Rescar (stichting ter bevordering research cardiologie) Maastricht. 
Aan Anneke

Jeroen en Manon en mijn ouders 


\section{Contents}

Chapter 1

Introduction

Chapter 2

Methods

Chapter 3

Value of electrocardiogram in diagnosing right ventricular involvement in patients with an acute inferior wall myocardial infarction.

\section{Chapter 4}

Value of lead $\mathrm{V}_{4} \mathrm{R}$ for recognition of the infarct coronary artery in acute inferior wall myocardial infarction.

\section{Chapter 5}

Intracoronary thrombolysis for acute myocardial infarction late after bypass surgery: Value of lead $V_{4} R$.

\section{Chapter 6}

Value of lead $V_{4} R$ in exercise testing to predict proximal stenosis of the right coronary artery.

\section{Chapter 7}

Right ventricular involvement with acute inferior wall myocardial infarction identifies high risk of developing atrioventricular nodal conduction disturbances. 


\section{Chapter 8}

Right and left ventricular ejection fraction after an acute inferior wall $m y-$ ocardial infarction with or without ST-segment elevation in $V_{4} R$.

\section{Chapter 9}

Conclusions

Summary 80

Samenvatting

Curriculum vitae

Acknowledgements 



\section{Chapter 1}

\section{Introduction}

Right ventricular infarction was initially a diagnosis only made by pathological observation. In a review of 2,000 consecutive autopsies Wartman and Hellerstein (1) in 1948 described 22 instances of right ventricular infarction out of 164 cases of myocardial infarction (13,8\% prevalence). In 18 hearts left and right ventricular infarction was observed whille 4 hearts had isolated right ventricular infarction. Wade (2) examined 19 postmortem hearts with right ventricular infarction and found occlusion of the right coronary artery in 18 specimens. Isner and Roberts (3) reported an incidence of $14 \%$ of right ventricular infarction in a group of 236 patients with a transmural infarction at necropsy. Right ventricular infarction was only found when transmural infarcts of the posterior septum was present. The incidence of right ventricular dilatation in combined inferior wall and right ventricular infarction was three times that found in the absence of right ventricular involvement $(\mathrm{p}<0.05)$. The characteristic hemodynamic manifestation of right ventricular infarction is a systemic venous hypertension in the presence of low left sided filling pressures (4). It is important to recognize this clinical entity because it requires specific therapy in the form of aggressive volume administration. Although invasive hemodynamic monitoring of patients with acute myocardial infarction has gained popularity in recent years, the technique is not available in every hospital. Non-invasive techniques to make the diagnosis of right ventricular infarction are therefore required. Better knowledge of the syndrome has been gained by the use of echocardiography $(5,6)$ and cardiac scintigraphy $(5,6,7,8)$. As electrocardiography is inexpensive and readily available, the purpose of this study was to assess the value of additional right precordial leads for diagnosing right ventricular infarction and to assess its value in locating the coronary artery lesion which is responsible for inferior myocardial infarction or recognize a critical stenosis in the right coronary artery. The predictive value of diagnosing right ventricular infarction with regard to subsequent $\mathrm{AV}$-block was also studied. Lastly, the effect of right ventricular infarction on the ejection fraction of the right ventricle in the acute phase of myocardial infarction was evaluated. 


\section{References}

\section{Wartman WB, Hellerstein HK:}

The incidence of heart disease in 2000 consecutive autopsies. Ann Intern Med 1948; 28: $41-65$.

2. Wade WG:

The pathogenesis of infarction of the right ventricle. $\mathrm{Br}$ Heart $J 1959 ; 21: 545-54$.

3. Isner JM, Roberts WC:

Right ventricular infarction complicating left ventricular infarction secundary to coronary heart disease. Frequency, location, associated findings and significance from analysis of 236 necropsy patients with acute or healed myocardial infarction. Am J Cardiol 1978; 42: $885-894$.

4. Cohn JN, Guiha NH, Broder MI, Limas CJ:

Right ventricular infarction: Clinical and hemodynamic features. Am $J$ Cardiol $1974 ; 33$; 209-214.

5. Candell-Riera I, Figueras J, Valle V, Alvarez A, Gutierrez L. Cortadellas I, Cinca I, Salas A, Rius I:

Right ventricular infarction: Relationships between ST-segment elevation in $V_{4} R$ and hemodynamic scintigraphy and echocardiographic findings in patients with acute inferior myocardial infarction. Am Heart J 1981; 101: 281-287.

6. Sharpe DN, Botvinick EH, Shames DM, Schiller DN, Massie BM, Chatterjee K, Parmley WW:

The noninvasive diagnosis of right ventricular infarction. Circulation 1978; 57: 483-490.

7. Rigo P, Murray M, Tayler DR, Weisfeldt ML, Kelly DT, Strauss HW, Pitt B:

Right ventricular dysfunction detected by gated scintiphoptography in patients with acute myocardial infarction. Circulation 1975; 52: 268-274.

8. Wackers FJTh, Lie KJ, Sokole EB, Res J, Van der Schoot JB, Durrer D:

Prevalence of right ventricular involvement in inferior wall infarction assessed with myocardial imaging with thallium 201 and technetium $99 \mathrm{~m}$ pyrophosphate. Am J Cardiol 1978; 42: 358-362. 


\section{Chapter 2}

\section{Methode}

This chapter describes the methods used in all the reported studies. Emphasis will be placed upon the right chest wall electrocardiogram, the radionuclide techniques applied and the invasive investigations used. Also the value and limitations of these techniques will be discussed.

\section{a. Right chest wall electrogram}

A standard 12-lead electrocardiogram is recorded from all patients admitted to our department using either a Siemens Elema Mingograph 626 channel recorder or a Marquette 40003 channel recorder with standard American Heart Assocation (AHA) filter settings (1).

Leads I, II, III, aVR, aVL, aVF and the unipolar precordial leads $\mathrm{V}_{1}-\mathrm{V}_{6}$ are recorded together with right sided chest leads.

Standard positions are used for lead $V_{1}-V_{0}$ and mirror image position for the right chest leads $V_{\|} R-V_{6} R$ (table 1 ). In this way, $V_{1}$ and $V_{2}$ are equal to the right sided leads $V_{2} R$ and $V_{1} R$ respectively. The placement of all the chest leads is illustrated in figure 1 .

Table 1

Lead No. Anatomical position

$V_{1}$

$V_{2}$

$\mathrm{V}_{3}$

$V_{4}$

$\mathrm{V}_{5}$

$V_{6}$

$V_{1} R$

$\mathrm{V}_{2} \mathrm{R}$

$V_{3} R$

$V_{4} R$

$V_{5} R$

$V_{6} R$ 4th ICS at right sternal border

4th ICS at left sternal border

Midway between $V_{2}$ and $V_{4}$

5 th ICS in left midclavicular line

At level of $V_{4}$ in left anterior axillary line

At level of $V_{4}$ in left midaxillary line

As $V_{2}$

As $V_{1}$

Midway between $V_{2} R$ and $V_{4} R$

5 th $\mathrm{ICS}$ in right midclavicular line

At level of $V_{4} R$ in right anterior axillary line

At level of $V_{4} R$ in right midaxillary line

Abbreviations: ICS $=$ Intercostal space 


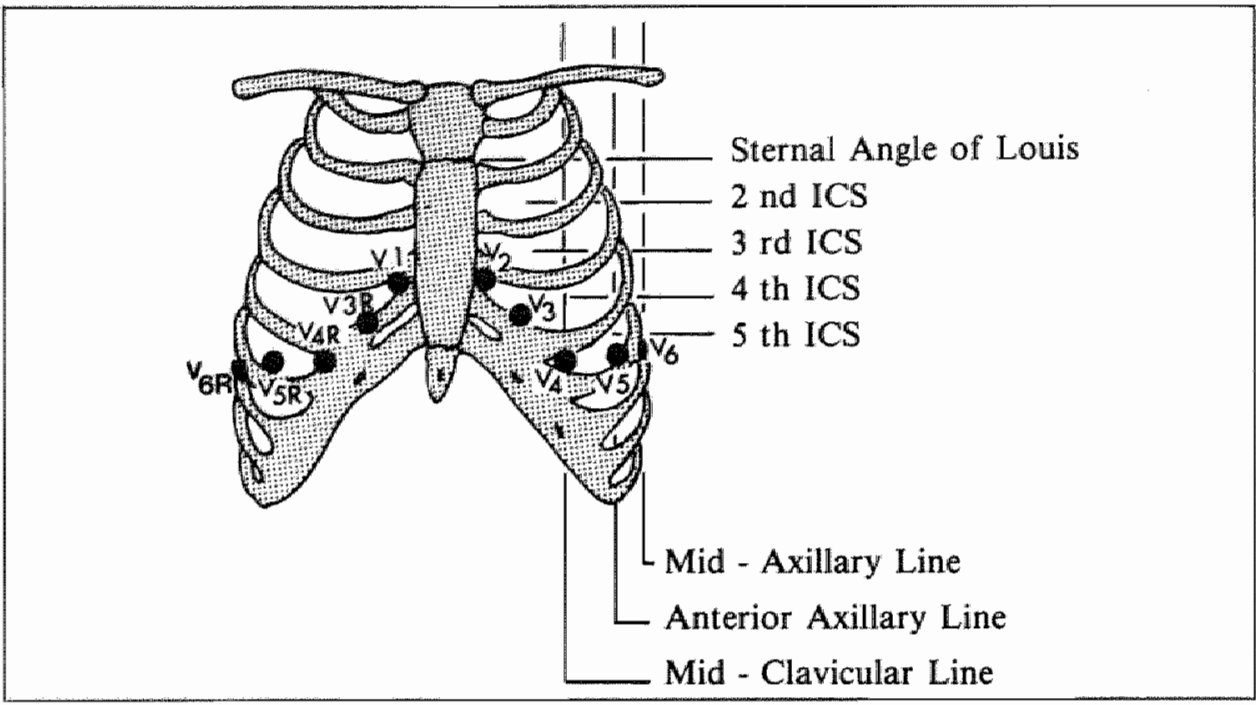

Figure 1 The placement of the right and left precordial leads.

The normal pattern of the right chest wall leads:

Before studying the pattern of electrocardiographic changes in the right chest wall leads in patients with myocardial infarction we defined the normal pattern in these leads. A standard 12-lead electrocardiogram and 6 right chest wall leads were recorded in 30 volunteers. None of the 30 volunteers (18 male, age range 22 to 35 years) had a history of ischemic heart disease. All had a normal 12-lead standard electrocardiogram. The pattern in the right chest wall leads was as follows: In lead $V_{1} R\left(V_{2}\right)$ an ST-segment elevation $\geqq 1 \mathrm{~mm}$ was seen in 20 volunteers $(18$ males and 2 females). They all showed the pattern of early ventricular repolarization with STsegment elevation at the J-point. The high incidence of early repolarization is probably accounted for by the low mean age (26 years) of this group.

In lead $V_{2} R\left(V_{1}\right) S T$-segment elevation $\geq 1 \mathrm{~mm}$ was observed in two subjects. None of the volunteers showed ST elevation $\geq 1 \mathrm{~mm}$ in lead $V_{3} R, V_{4} R, V_{5} R$ and $V_{6} R$. A QS-pattern was seen in $V_{3} R$ and $V_{4} R$ in 2 volunteers. In 27 a negative $T$-wave was observed in the right precordial leads. We conclude that in normals the right chest wall leads do not show $S T$ elevation $\geqq 1 \mathrm{~mm}$ in $V_{2} R, V_{3} R, V_{4} R, V_{5} R$ and $V_{6} R$. A QS-pattern in lead $V_{3} R$ and $V_{4} R$ and ST-segment elevation in $V_{2} R\left(V_{1}\right)$ is seen infrequently. The majority of normals show negative $T$-waves in the right precordial leads. Our volunteers represent an age group younger than our patients with myocardial infarction (mean age 57 years). We were unable to find an age-matched control group of patients free from cardiac symptoms. 


\section{b. Radionuclide techniques used in this study}

\section{Pyrophosphate imaging for infarct detection}

In 1974 Bonte et al (2) reported that technetium $99 \mathrm{~m}$ labeled to stannous pyrophosphate localized in acutely infarcted myocardium in animal studies. This technique has also prowed sensitive for identifying acutely infarcted myocardial tissue in humans $(3,4)$. The mechanism of Tc99m stannous pyrophosphate binding in such tissues has yet to be clearly defined.

\section{Technique}

Technetium $99 \mathrm{~m}$ stannous pyrophosphate was the first agent used to image acute myocardial infarction in both the animal and the human heart. Dosages of $15 \mathrm{mC}$ to $20 \mathrm{mC}$ technetium $99 \mathrm{~m}$ tagged to $5 \mathrm{mg}$ of stannous pyrophosphate were most commonly used for acute myocardial necrosis imaging in our studies. Imaging of the heart was started at between 60 and 90 minutes following the injection of the radionuclide. The postinfarction timing of the study was 36-72 hours after the onset of chest pain.

Good labeling of the phosphate compounds with technetium $99 \mathrm{~m}$ is required to prevent poor clearance of the tracer from the blood pool. This could simulate diffuse tracer concentration in the myocardium and give rise to positive interpretation. Tc $99 \mathrm{~m}$ stannous pyrophosphate must be injected within 1 hour of its preparation to minimize release of the $\mathrm{Tc} 99 \mathrm{~m}$ from its binding compound.

\section{Equipment}

This radionuclide technique requires a gamma camera and a computer to process the images. The gamma camera should have a high resolution, high sensitivity or an all purpose collimator. Field uniformity is essential as warm areas in the field can be erroneously interpreted as a positive myocardial scintigram.

In our studies we used either a Philips camera with a parallel hole all purpose collimator interfaced to a Philips mini-computer P855M or an Ohio Nuclear Sigma 420 mobile gamma camera interfaced to a MCS 560 mobile Ohio Nuclear computer. We used a $20 \%$ window, which was set symmetrically around the $140 \mathrm{KEV}$ photopeak of technetium $99 \mathrm{~m}$.

\section{Positioning}

Patients were routinely imaged in the supine position using the anterior and $45^{\circ}$ left anterior oblique projections. Left lateral views were obtained with the patient lying on his right side, to minimize the distance between the heart and the camera and thus preserve a high resolution. More than 600,000 counts were collected in each view, 60 to 90 minutes after the injection of technetium $99 \mathrm{~m}$ stannous phosphate i.v. 


\section{Image interpretation}

The sensitivity and specificity of technetium $99 \mathrm{~m}$ stannous phosphate scintigraphy is dependent on camera field uniformity, radiopharmaceutical stability, tagging efficiency and postinjection and postinfarction timing.

Scintigrams are commonly graded 0 to $4+$ depending on the activity over the myocardium. Grading refers to the intensity of the suspected lesion and not to its size. $O$ represents no activity and $1+$ indicates minimal activity believed to be in blood pool or chest wall. $2+$ indicates definite myocardial activity, $3+$ activity equal to bone activity and $4+$ activity greater than bone activity. This system has been shown to have a good correlation with electrocardiographic and enzymatic criteria for determining the presence of infarction. Inferior myocardial infarcts are visualized as platelike areas of activity extending to the left of the sternum in anterior views.

Parkey (5) found this technique to be highly accurate. Only $4 \%$ of false negative scintigrams were found while false positive results range from 8 to $12 \%$ when the ECG is used as the gold standard. The false positive scintigrams were found in patients with unstable angina.

\section{Anatomic location of the right and left ventricle}

To determine the borders of the right and left ventricle a bolus $5 \mathrm{mCi}$ technetium was injected with the patients in the left anterior oblique position $\left(45^{\circ}\right)$. A dynamic flow study was recorded using a frame rate of one per second. The right atrium, right ventricle, lungs, left atrium, left ventricle and aorta were visualized separately. This enabled a region of interest (ROI) representing the right ventricle to be determined. This ROI was then superimposed on the $45^{\circ}$ left anterior oblique view of the technetium $99 \mathrm{~m}$ stannous phosphate image to asses the presence of activity localized to the right ventricle free wall.

\section{Limitations}

Areas of acute myocardial infarction cannot be reliably defined by scintigraphy with intravenous injection of technetium $99 \mathrm{~m}$ stannous pyrophosphate for at least 24 hours after the onset of chest pain. Earlier imaging with this radionuclide can only be achieved if direct intracoronary injection is performed.

Using the ECG combined with serial enzyme estimation as the "gold standard" for infarct detection, technetium $99 \mathrm{~m}$ stannous pyrophosphate imaging is found to result in $4 \%$ false negative scintigrams. In our studies there were no false negatives, probably because only patients with transmural infarction and an enzyme rise to at least twice normal values were included. Though infarct imaging requires only small and therefore inexpensive, quantities of technetium $99 \mathrm{~m}(15-25 \mathrm{mCi})$ high quality data cannot be obtained without a reliable gamma camera and computer system. This equipment is relatively expensive and limits the availability of this technique. 


\section{d. Multigated cardiac blood pool imaging}

In this technique, images of the blood pool in the heart at fixed points in the cardiac cycle are obtained by synchronizing the recording of scintillation data to an indicator of cardiac contraction, such as the electrocardiogram. Using a physiological signal that occurs at a fixed time in relation to the mechanical activity of the heart to gate the recording of scintillation events, repetitive sampling during specific phases of many consecutive cardiac cycles enables images of reasonable count density to be recorded.

A high-quality blood pool label is critical for the acquisition of high resolution data in a short imaging interval. The relationship between activity in the cardiac blood pool and that in the pulmonary blood pool background will determine the accuracy with which the borders of the chambers can be defined for a given count density of data. Technetium $99 \mathrm{~m}$ currently appears to be the most appropriate radionuclide for use with the scintillation camera. The binding agents that have been suggested as blood pool labels include both albumen (6) and red blood cells (7). Albumen has a relatively large distribution volume compared to that of red blood cells. This volume includes the liver and to a lesser extent the lungs. Images recorded with this radiopharmaceutical will therefore have a lower heart to lung activity ratio than those recorded with labeled red blood cells (8). However, even with the technetium $99 \mathrm{~m}$ labeled red blood cells a heart to lung ratio of only $3: 1$ can be achieved.

Both in vivo and in vitro methods have been proposed to achieve cell labeling. There is no evidence of any difference between there methods in terms of the results obtained in the clinical situation (7).

In our clinic we use the method described by Pavel et al (9). Fifteen to 30 minutes after an intravenous injection of a stannous pyrophosphate solution $(5 \mathrm{mg})$ a second intravenous injection with $15-20 \mathrm{mCi}$ technetium $99 \mathrm{~m}$ pertechnetate is given. The technetium $99 \mathrm{~m}$ binds almost instantaneously to the globin portion of the hemoglobin with a labeling efficiency of well over $90 \%$ and does not clear from the cells for several hours. As described by Alderson (10) the unlabeled portion of the injected does appears to clear rapidly from the body in the urine; thus a high target to background activity ratio is maintained over the heart.

\section{Imaging technique}

We used a Philips camera with a parallel hole-all-purpose collimator interfaced to a Philips minicomputer (P855M). Data were collected in three different views: anterior, left lateral and left anterior oblique $\left(30-55^{\circ}\right)$. In the latter view, the best separation between the right and left ventricle could be achieved. We used a $20 \%$ window which was set symmetrically around the $140 \mathrm{KEV}$ photopeak of technetium. Data were collected and stored on disc in synchronized frame mode by dividing an average cardiac cycle into 32 frames with $64 \times 64$ pixel elements. 
Processing methods used in our studlies

\section{Arrhythmia filtering program}

Cycles that were either too long or too short with respect to the mean were rejected. The limits of acceptable cycle length were defined as $+20 \%$ of the average RRinterval. Because of the variation in heart rate, the acquisition time for each frame was not constant. A correction factor was therefore derived from the RR-interval of each cycle. Acquisition time for each view is 300 seconds.

\section{Processing methods for LVEF and RVEF calculation}

After acquisition of the data a semi-automatic program was initiated to perform a three dimensional filter process in space $(X, Y)$ and time $(T)$. This filter system enables the reservation of important information regarding organ structure and movement. After completion of the filter program, a region of interest was placed around the left or right wentricle in the end-diastolic frame. Edge detection of the ventricles was performed by means of the second derivative of count activity.

The second derivative was determined with a 7 point Laplace operator in 4 independent directions. This algorithm can be used to construct a closed contour around either the right or left ventricle. A variable region of interest was thus constructed for each of the 32 frames representing a cardiac cycle. Background correction was determined from the end-systolic frame. RVEF and LVEF were calculated according to

$$
\begin{array}{cl}
\mathrm{EF}=\frac{\mathrm{EDC}-\mathrm{ESC} \times 100 \%}{\mathrm{EDC}} & \mathrm{EDC}=\text { end-diastolic counts, } \\
\mathrm{ESC}=\text { end-sysolic counts }
\end{array}
$$

To determine normal limits for LVEF and RVEF 20 patients were studied. Ten were male and the age range was 28-63 years. Ten of these patients had no cardiac history, and were studied just before the first treatment with adriamycin for breast cancer. The remaining patients were studied 2 days after diagnostic heart catheterisation for the investigation of chest pain. None had a history of myocardial infarction and in all ten the ventriculograms were judged to be normal. The right and left ventricular ejection fraction were determined in these patients by multigated blood pool imaging. The lower limits of normal LVEF and RVEF were then defined as the mean minus twice the standard deviation of the ejection fraction in the group. Values of $60 \%$ for LVEF and $40 \%$ for RVEF were found.

\section{Validation of the ejection fraction calculation}

The ejection fraction calculated from the left ventriculogram is still regarded as the "gold standard". This method to determine ejection fraction will be described in the section on angiographic techniques. To validate the results of ejection fraction by nuclear imaging, we assessed the correlation between values obtained with this technique and those calculated from the left ventriculogram in the same group of 
patients. Forty consecutive patients (32 male, age range 34-68 years) who were admitted for cardiac catheterisation were also studied by nuclear angiography. There was close correlation between the values of LVEF determined by the two methods ( $\mathrm{r}=0.84$ ) (fig. 2).

In the absence of any other reliable means of determining RVEF, it is impossible to validate the values obtained by nuclear techniques. The calculation of the right ventricular ejection fraction in a multigated study is complicated by the changing overlap of the right atrium. Because there are no reasons to believe that there is a difference between the overlap of the right atrium in patients with or without right ventricular infarction, we believe that we were justified in comparing the value of RVEF, derived by multigated nuclear angiography in the two groups (chapter 5). Because we used a "semi" -automatic program for calculation of the right and left ventricular ejection fraction the inter and intraobserver variability is zero.

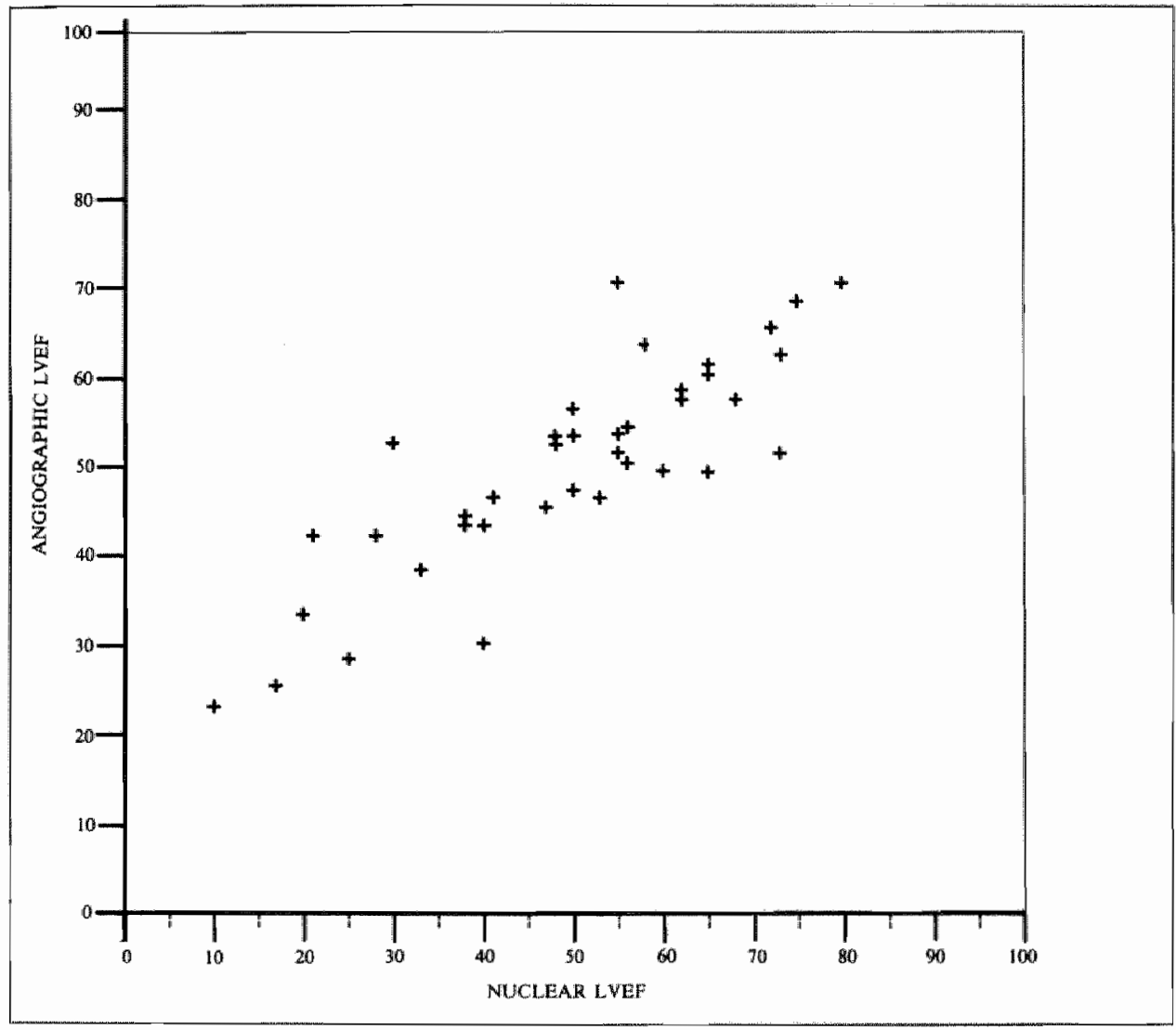

Figure 2 The relation between the radionuclide and angiographic left ventricular ejection fraction. 


\section{e. Angiographic techniques used in our studies}

After local anaesthesia with lidocain $2 \%$, a French 8 Cordis pigtail catheter was introduced percutaneously into a femoral artery using the Seldinger technique. Following hemodynamic measurements, left ventriculography was performed using $60^{\circ} \mathrm{LAO}$ (left anterior oblique) and $30^{\circ} \mathrm{RAO}$ (right anterior oblique) projections. In our catheterisation لaboratory we have a Siemens U-arm angioscope. Cine films were taken at 50 frames per second by a $35 \mathrm{~mm}$ Arriflex camera mounted on a 9 inch image intensifier. The films were developed using an Oude Delft processor.

\section{Measurement of the ejection fraction on the left ventriculogram}

The films were projected on an Arriflex RGT screen. A transparant sheet of paper was fixed on the screen and the end-systolic and end-diastolic contours in the right anterior oblique position drawn on this paper. The left ventricle ejection fraction was calculated from these contours by means of Hewlett Packard digitizer (9874A) and computer (9830A).

\section{Coronary arteriography}

Following left ventriculography, coronary angiography was performed using Judkins catheters. The right coronary artery was studied in 2 projections: LAO $60^{\circ}$ and RAO $30^{\circ}$. The left coronary artery was studied in 4 projections: LAO $60^{\circ}$, LAO with craniocaudal tilt, RAO $30^{\circ}$ and RAO with caudocranial tilt. The resulting cine films were projected using a Tagarno $35 \mathrm{CX}$. A visual assessment of the degree of stenosis was determined by 2 observers. Callipers measurement was used to resolve any interobserver disagreement.

\section{References}

1. Report of the Committee on electrocardiography. American Heart Association. Recommendation for standardization of leads and of specifications for instruments in electrocardiography and vectorcardiography. Circulation 35: March 1967

2. Bonte F, Parkey RW, Graham KD et al:

A new method for radionticlicle imaging of myocardial infarcts. Radiology 110: 473, 1974.

3. Parkey RW, Bonte FJ, Meyer SL et al:

A new method for radionulcide imaging of acute myoardial infarctions in humans. Circulation $50 ; 540,1974$

4. Bonte FJ, Parkey RW, Graham KD et al:

Distribution of several agents useful in imaging myocardial infarcts. J Nucl Med 16: 132, 1975 
5. Parkey RW, Bonte FJ, Stokley EM et al:

Acute myocardial infarction imaged with technetium $99 \mathrm{~m}$ stannous pyrophosphate and thallium 201. A clinical evaluation. J Nucl Med 17: 771, 1976.

6. Straus HW, Zaret BL, Huxley PJ, Natarajan TK, Pitt B:

A scintiphotographic method for measuring left ventricular ejection fraction in man without cardiac catheterization. Am J Card 28: 575, 1971.

7. Hegge FN, Hamilton GW, Larson SM et al:

Cardiac chamber imaging: A comparison of red blood cells labeled with $\mathrm{Tc} 99 \mathrm{~m}$ in vitro and in vivo. J Nucl Med 19: 129, 1978.

8. Thrall JH, Freitas JE, Swanson D, Rogers WL. Clare JM, Brown ML, Pitt B: Clinical comparison of cardiac blood pool cells labeled in vivo and with technetium $99 \mathrm{~m}$ human serum albumen. J Nucl Med 19: 796, 1978.

9. Pavel DG, Zïmmer AM, Patterson VN:

In vivo labeling of red blood cells with technetium $99 \mathrm{~m}$ : A new approach to blood pool visualization. J Nucl Med 18: 305, 1978.

10. Alderson PO, Hamilton RG:

A comparative evaluation of techniques for rapid and efficient in vivo labeling of red cells with technetium 99m pertechnetate. J Nucl Med 18: 1008, 1977. 



\section{Chapter 3}

Value of electrocardiogram in diagnosing right ventricular involvement in patients with an acute inferior wall myocardial infarction

by

Simon H. Braat, MD, Pedro Brugada, MD,

Christoffel de Zwaan, MD, Joseph M. Coenegracht, MD, Hein J.J. Wellens, MD. Department of Cardiology

and Nuclear Medicine Annadal Hospital, University of Limburg Maastricht, The Netherlands

Published in the British Heart Journal 1983, 49"368-72 and in part presented at the 54th Annual Scientific Meeting of the American Heart Association, Dallas, November 1981 


\section{Summary}

To study the value of the electrocardiogram in diagnosing right ventricular involvement in acute inferior wall myocardial infarction the electrocardiographic findings were analysed in 67 patients who had had scintigraphy to pin-point the infarct. All 67 patients were consecutively admitted because of an acute inferior wall infarction. A 12 lead electrocardiogram with four additional right precordial leads $\left(V_{3} R, V_{4} R\right.$, $V_{5} R$ and $V_{6} R$ ) was routinely recorded on admission and every 8 hours thereafter for three consecutive days. Thirty-six to 72 hours after the onset of chest pain a $99 \mathrm{~m}$ technetium pyrophosphate scintigraphy and a dynamic flow study were performed to detect right ventricular involvement, which was found in 29 of the 67 patients (43\%). ST-segment elevation $\geq 1 \mathrm{~mm}$ in leads $V_{3} R, V_{4} R, V_{5} R$ and $V_{6} R$ is a reliable sign of right ventricular involvement. ST-segment elevation $\geqq 1 \mathrm{~mm}$ in lead $V_{4} R$ was found to have the greatest sensitivity $(93 \%)$ and predictive accuracy $(93 \%)$. The diagnostic value of a QS pattern in lead $V_{3} R$ and $V_{4} R$ or $S T$ elevation $\geqq 1 \mathrm{~mm}$ in lead $V_{1}$ was much lower. ST-segment elevation in the right precordial leads was short lived, having disappeared within 10 hours after the onset of chest pain in half of our patients with right ventricular involvement. When electrocardiograms are recorded in patients with an acute inferior wall infarction within 10 hours after the onset of chest pain, additional right ventricular infarction can easily be diagnosed by recording lead $V_{4} R$.

Until recently, the diagnosis of right ventricular infarction was only possible at necropsy. In 1948, in their review of 2000 consecutive necropsies, Wartman and Hellerstein (1) described 22 instances of right ventricular infarction out of 164 cases of myocardial infarction. At necropsy of 19 hearts with right ventricular infarction, Wade (2) found that the major damage was located on the posterior wall of the heart. In all 19 patients the electrocardiogram had shown an inferior wall myocardial infarction.

In 1974 Cohn et al (3) reported characteristic haemodynamic changes in six patients with an inferior wall myocardial infarction, who also had right ventricular infarction. Sharpe et al (4) observed that six out of 15 patients with an inferior wall infarction showed abnormal technetium pyrophosphate uptake in the right ventricle. In a study of patients with an acute inferior wall myocardial infarction Wackers et al (5) found that in $37 \%$ the technetium pyrophosphate uptake also showed involvement of the right ventricle.

Erhardt et al (6) in 1976 described the value of a right precordial lead $V_{4} R$ in diagnosing right ventricular involvement. They compared their data with necropsy findings and found right ventricular infarction in 9 out of 18 patients $(50 \%)$. These data have subsequently been confirmed by other investigators (7). Recently, Chou et al (8) described the value of lead $V_{\|}$in diagnosing right ventricular infarction in 11 pa- 
tients. The diagnosis of right ventricular infarction was proven at necropsy and supported by hemodynamic findings. Morgera et al (9) in a preliminary report described the value of a $Q S$ pattern in lead $V_{3} R$ and $V_{4} R$ in diagnosing right ventricular infarction.

The incidence of abnormal hemodynamic findings suggesting right ventricular infarction is much lower than findings pointing to right ventricular involvement at necropsy or scintigraphy. Therefore we decided to compare the value of the different electrocardiographic criteria in diagnosing right ventricular infarction in patients with inferior wall infarction when additional right ventricular involvement was shown by $99 \mathrm{~m}$ Technetium pyrophosphate scintigraphy.

\section{Patients and methods}

Studies were made on 67 consecutive patients ( 56 men, 11 women), admitted because of an acute inferior wall infarction. Four had a documented myocardial infarction in the past, in two on the anterior and in two on the inferior wall.

Patients were admitted half an hour to 30 (mean five) hours after the onset of chest pain. Ages ranged from 39 to 80 (mean $57 \pm 9.4$ ) years. The diagnosis of acute inferior wall infarction was based on the clinical history, a characteristic enzyme pattern of CPK and AST values, and the appearance of new pathological Q waves in the inferior leads (II, III and AVF). On admission and every eight hours during the next three days a 12 lead ECG and four additional right precordial leads were recorded (Fig. 1).

The amount of ST elevation in lead $V_{1}$, and in leads $V_{3} R, V_{4} R, V_{5} R$ and $V_{6} R$ (these leads are the mirror image of leads $V_{3}, V_{4}, V_{5}$ and $V_{6}$ ), was measured and the duration of its presence noted. We also looked for the presence of a QS pattern in leads $V_{3} R$ and $V_{4} R$.

At the time of the electrocardiographic registrations blood was taken to determine the values for CPK and AST. Normal values for CPK and AST in our laboratory are, respectively, less than 240 and $40 \mathrm{U} / \mathrm{l}$. None of the 67 patients had clinical signs of right ventricular infarction on physical examination. No hemodynamic monitoring was performed in any of the patients. Thirty-six to 72 hours after the onset of chest pain a $99 \mathrm{~m}$ Technetium pyrophosphate scintigraphy was performed. A Philips scintillation camera with a general all purpose parallel hole collimator interfaced to a PDS computer system or a Ohio Nuclear Sigma 420 mobile gamma camera with a general all purpose parallel hole collimator interfaced to a MCS 560 mobile computer system was used for all studies. One hour after the injection of 15 to $20 \mathrm{mCi}$ of $99 \mathrm{mTechnetium} \mathrm{pyrophosphate,} \mathrm{the} \mathrm{anterior,} \mathrm{the} \mathrm{left} \mathrm{lateral,} \mathrm{and} \mathrm{the} 45^{\circ}$ left anterior oblique views were recorded with a general all purpose parallel hole collimator 
(Fig. 2). Each view contained at least 600,000 counts. After the last view was recorded, which was always the $45^{\circ}$ left anterior oblique, a small bolus of $99 \mathrm{~m}$ Technetium was injected without moving the patient or the collimator.

Simultaneously a dymamic flow study was performed, using frames of one second to visualise separately the right and left ventricle (Fig. 3).

A region of interest was placed around the right and left ventricle and these regions of interest were superimposed on the left anterior oblique view to verify whether there was right ventricular involvement (Fig. 4).

The radionuclide data were analysed by two independent observers without knowledge of the clinical data. The $99 \mathrm{~m}$ Technetium pyrophosphate scintigraphy was judged to be positive when there was myocardial uptake. Right ventricular involvement was considered to be present if definite myocardial uptake was seen in the region of interest of the right ventricle.

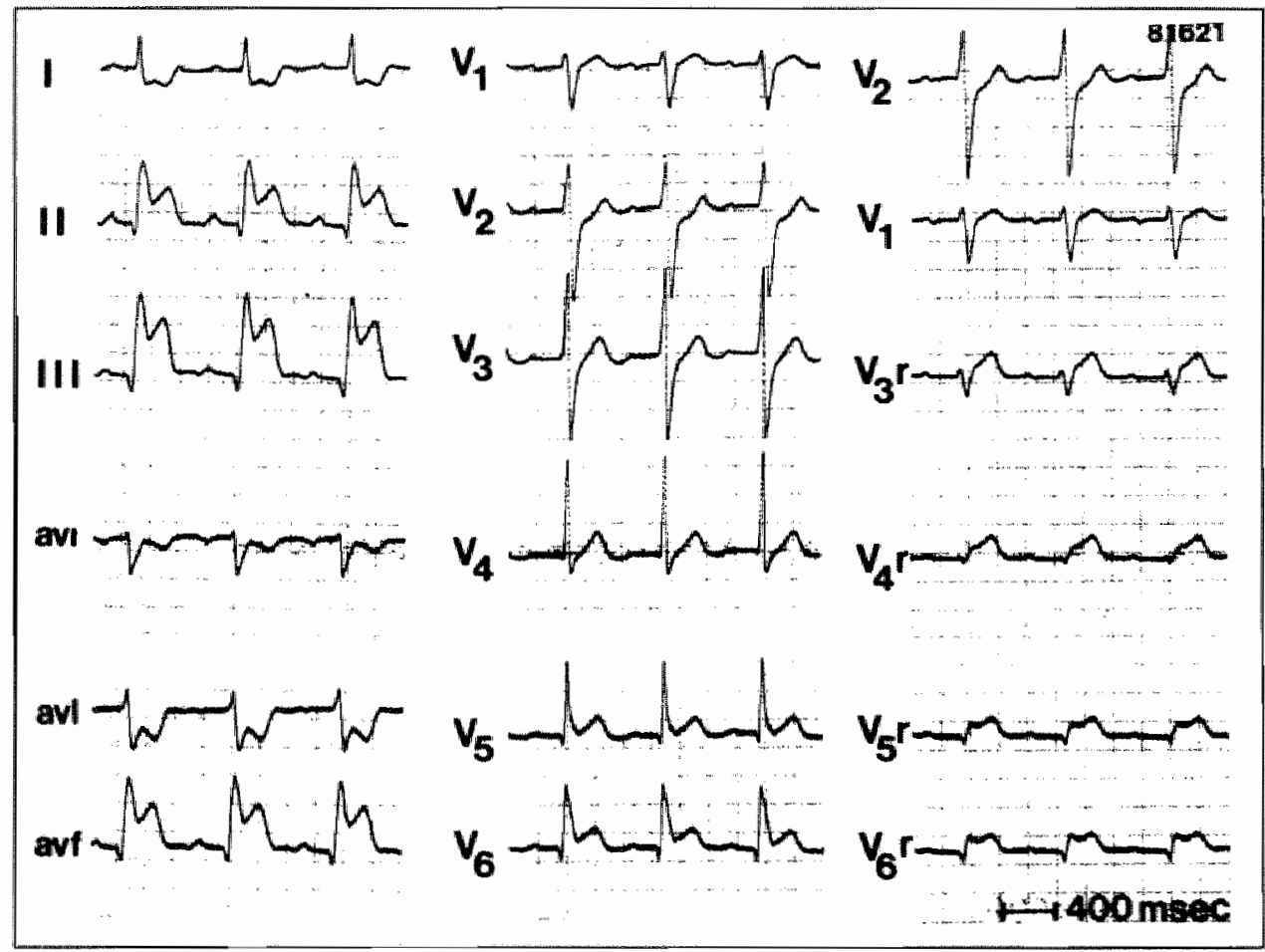

Figure 1 Leads I, II, III, AVR, AVL, AVF, leads $V_{1}, V_{2}, V_{3}, V_{4}, V_{5}, V_{6}$ and leads $V_{2}, V_{1}, V_{3} R, V_{4} R, V_{5} R$ and $V_{6} R$ are recorded simultaneously. This electrocardiogram shows an acute inferolateral wall myocardial infarction. The right precordial leads show $S T$-segment elevation in leads $V_{3} R, V_{4} R, V_{5} R$ and $V_{6} R$, in the absence of a QS-pattern in lead $V_{3} R$ or $V_{4} R$ or ST-segment elevation in lead $V_{1}$. 


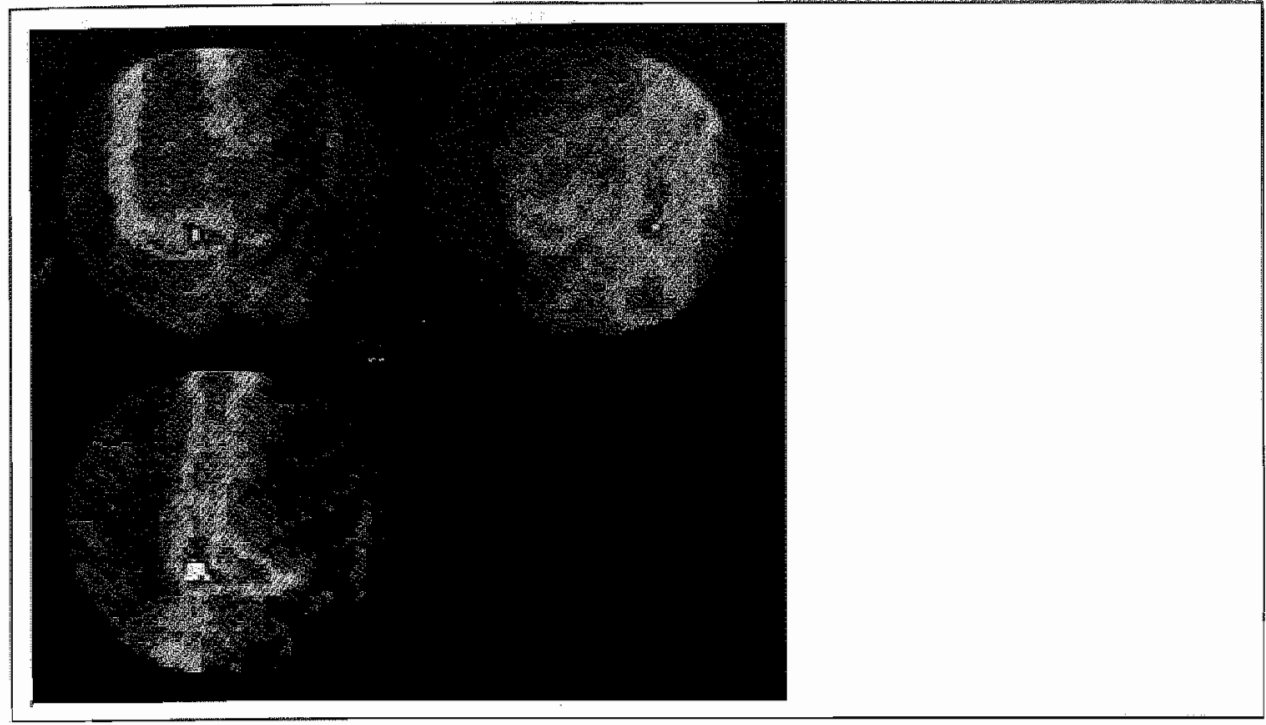

Figure 2 An example of a $99 \mathrm{mTechnetium} \mathrm{pyrophosphate} \mathrm{scan} \mathrm{in} \mathrm{three} \mathrm{different}$ views. Top left the $45^{\circ}$ left anterior oblique view. On the right, the left lateral, and below the anterior view. Apart from uptake in the sternum, spine, and ribs, pathological $99 \mathrm{~m}$ Technetium pyrophosphate uptake is seen in the inferior wall of the myocardium.

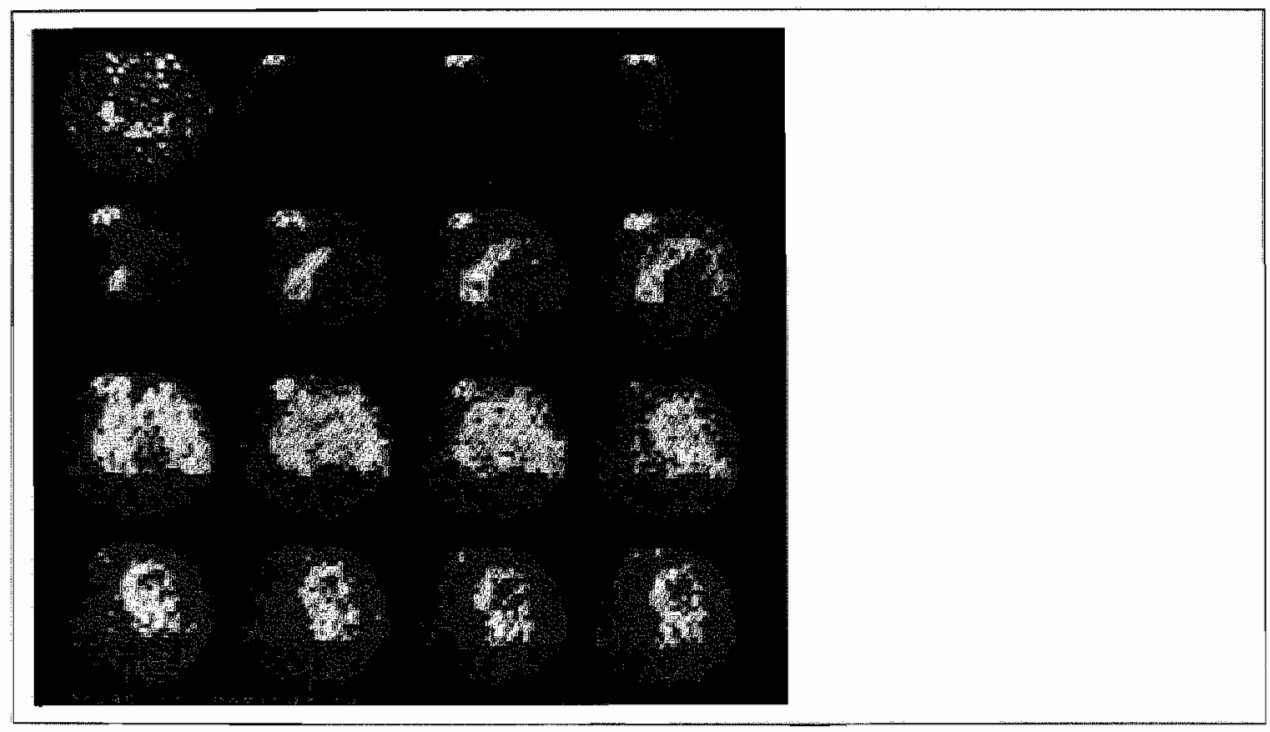

Figure 3 An example of a dynamic flow study. The activity can be followed from the superior caval vein to the right ventricle, the lungs, the left ventricle, and the aorta. 


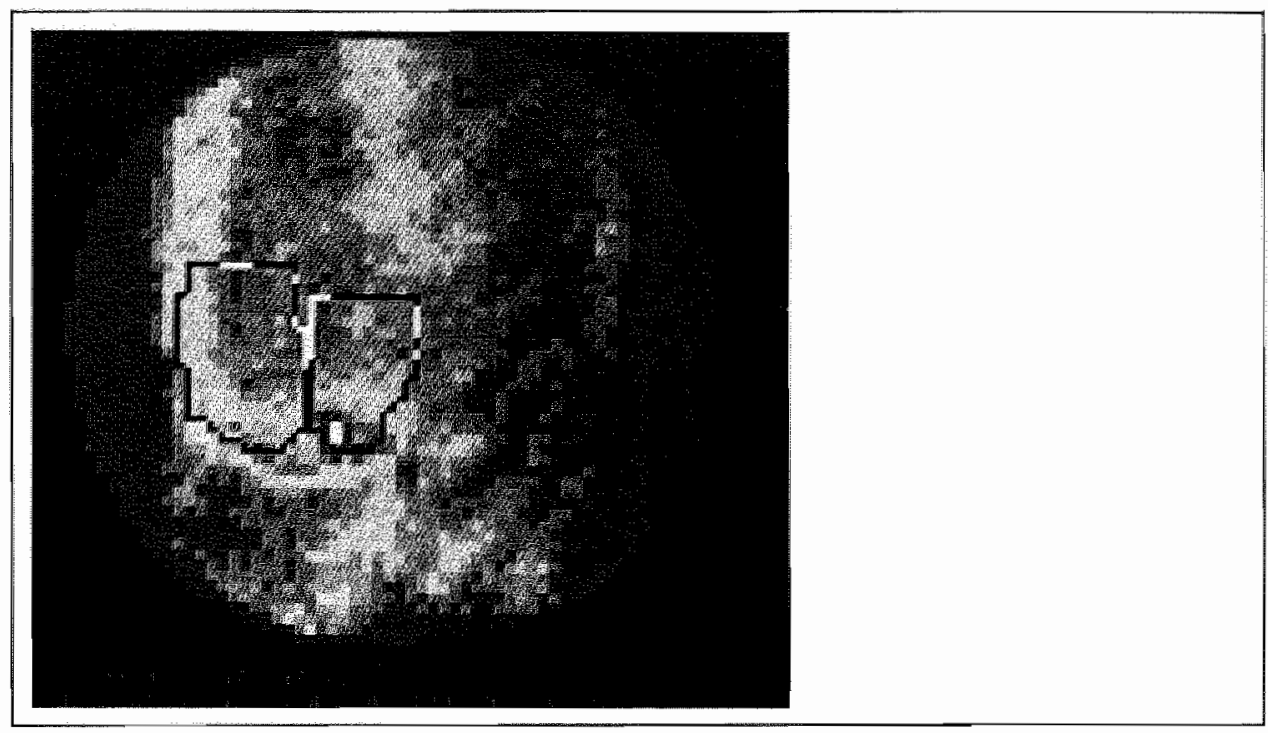

Figure 4 The $45^{\circ}$ left anterior oblique view on which is superimposed the region of interest drawn around the right and left ventricle. Definite involvement of the right ventricle is seen.

\section{Results}

All 67 patients had pathologic uptake of $99 \mathrm{~m}$ Technetium pyrophosphate in the inferior wall. Twenty-nine patients ( $43 \%$ ) also had right ventricular involvement. Twentyone patients had ST-segment elevation $\geqq 1 \mathrm{~mm}$ in lead $V_{3} R$. Only in one patient did the scan not show right ventricular involvement. Twenty-nine patients had STsegment elevation in lead $V_{4} R \geq 1 \mathrm{~mm}$. In two of this group there was no right ventricular involvement on the $99 \mathrm{~m}$ Technetium scan. In only 3 of the 29 patients with STsegment elevation in lead $V_{4} R \geq 1 \mathrm{~mm}$ did this elevation persist for more than 72 hours.

In 14 patients the duration of significant ST elevation lasted less than 10 hours after onset of chest pain. In the two patients without ST elevation in lead $V_{4} \mathbb{R}$ but with a positive $99 \mathrm{mTC}$ scan, 15 to 30 hours, respectively, had elapsed before arrival in hospital.

In addition, in 29 patients there was ST-segment elevation in lead $V_{5} R$. Three of them had no pathological $99 \mathrm{~m}$ Technetium uptake in the right ventricle. Twenty-seven patients had ST elevation $\geq 1 \mathrm{~mm}$ in lead $V_{6} R$. As shown in table 1 , in 3 cases there was disagreement between the electrocardiographic and the scintigraphic data.

Sixteen patients with a QS-pattern in leads $V_{3} R$ and $V_{4} R$ had right ventricular invol- 
vement on the scan. Of the 29 patients with scintigraphic right ventricular infarction only 8 had ST elevation in lead $V_{1} \geq 1 \mathrm{~mm}$. A false positive QS-pattern in lead $V_{3} R$

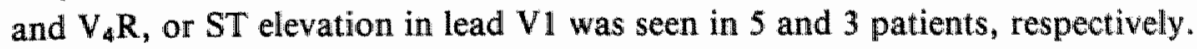

Table 2 shows the sensitivity, specificity and predictive accuracy of $S T$ elevation $\geq$ $1 \mathrm{~mm}$ in leads $V_{1}, V_{3} R, V_{4} R, V_{5} R, V_{6} R$ and of a QS-pattern in leads $V_{3} R$ and $V_{4} R$.

\section{Table 1}

Presence of ST segment elevation in leads $V_{3} R, V_{4} R, V_{5} R$ and $V_{6} R$ in patients with acute inferior wall infarction with and without right ventricular involvement.

ST elevation $>1 \mathrm{~mm}$

Positive pathological $99 \mathrm{mTc}$ uptake in right ventricle

Negative pathological $99 \mathrm{mTc}$ uptake in right ventricle

\section{No ST elevation $\geqq 1 \mathrm{~mm}$}

True negative

False negative

$\begin{array}{llll}\mathbf{V}_{3} R & \mathbf{V}_{4} \mathbf{R} & \mathbf{V}_{5} R & \mathbf{V}_{6} \mathbf{R}\end{array}$

20

27

26

24

1

2

3

3

$\begin{array}{rrrr}37 & 36 & 35 & 35 \\ 9 & 2 & 3 & 5\end{array}$

Table 2

Sensitivity, specificity and predictive accuracy of ST-segment elevation $\geqq 1 \mathrm{~mm}$ in leads $V_{1}, V_{3} R, V_{4} R, V_{5} R$ and $V_{6} R$ and a QS-complex in leads $V_{3} R$ or $V_{4} R$ in diagnosing right ventricular involvement in patients admitted because of an acute inferior myocardial infarction.

ST-segment

elevation

\section{$\geqq 1 \mathrm{~mm}$}

$V_{1}$

$\mathrm{V}_{3} R$

$V_{4} R$

$\mathrm{V}_{5} \mathrm{R}$

$\mathrm{V}_{6} R$

\section{QS-pattern}

$V_{3} R$

$\mathrm{V}_{4} \mathrm{R}$
Sensitivity

28

69

93

90

83

Specificity

Predictive accuracy 
The mean peak AST value of all the 67 patients was $255 \pm 120 \mathrm{U} / \mathrm{l}$. In the 29 patients with right ventricular infarction the mean AST was $271 \pm 120 \mathrm{U} / 1$ and in the 38 patients without right ventricular infarction $243 \pm 118 \mathrm{U} / \mathrm{l}$. This difference has no statistical significance. The mean peak CK value of all the patients was $2262 \mathrm{U} / \mathrm{A}$ and here also there was no statistical significant difference between the patients with and without right ventricular infarction (respectively $2321 \pm 1548 \mathrm{U} / \mathrm{A}$ and 2177 $\pm 1418 \mathrm{U} / 1$ ). Only one of the patients died in hospital, suddenly on the third day after admission, and cardiac tamponade was found at autopsy.

This patient had a positive scintigraphy for right ventricular involvement and $S T$ elevation $>1 \mathrm{~mm}$ in lead $V_{3} R, V_{4} R, V_{5} R$ and $V_{6} R$, but no $Q S$-pattern in lead $V_{3} R$ or $V_{4} R$, nor $S T$ elevation in $V_{1}$. At necropsy apart from an inferoposteroseptal infarction right ventricular involvement was also found.

\section{Discussion}

Since Cohn et al (3) in 1974 reported on the value of recognizing additional right ventricular infarction in patients with inferior wall infarction, interest in diagnosing this abnormality has grown. Since then it has become clear, however, that the clinical and hemodynamic features of right ventricular infarction are found in only a small percentage of patients showing right ventricular infarction at necropsy or during cardiac scintigraphy (10). In our series $43 \%$ of patients with an inferior wall myocardial infaretion had right ventricular involvement. Maximal enzyme values and clinical course during admission were not different in patients with and without additional right ventricular infarction. Because of the high incidence of atrioventricular nodal conduction disturbances in patients with inferior wall myocardial infarction with associated right ventricular infarction (11), we feel that it is desirable to have an easy and cheap tool to detect right ventricular involvement. Our results indicate that lead $V_{4} R$ is the single most valuable electrocardiographic lead to detect right ventricular involvement. It is of importance to stress, however, that the duration of ST-segment elewation is short, disappearing in less than 10 hours in $48 \%$ of our patients with right ventricular infarction.

This indicates the necessity for early recording of the right precordial leads. Our data indicate that ST elevation in lead $V_{4}$ or a QS-pattern in $V_{3} R$ and $V_{4} R$ does not have the same diagnostic value as $S T$-segment elevation in leads $V_{3} R, V_{4} R, V_{5} R$ and $V_{6} R$. In addition, a combination of $V_{4} R$ and $V_{1}$ or $V_{4} R$ and a $Q S$-pattern in $V_{3} R$ or $V_{4} R$ does not improve the diagnostic accuracy of the electrocardiogram in making the diagnosis of right ventricular infarction.

The most consistent finding in our patients with right ventricular infarction was the ST-segment elevation in the right precordial leads. Necropsy data have shown that right ventricular infarction is seen almost exclusively in patients with inferior wall 
infarction in combination with posteroseptal involvement. Perhaps the ST-segment elevation in the right precordial leads is an expression of posteroseptal involvement. The finding of a $Q S$-pattern in $V_{4} R$ and $V_{3} R$ requires further study. Again this could be the result of the loss of septal forces from the infarcted posteroseptal area. The incidence of a QS-pattern in right precordial leads in patients without myocardial infarction is, however, not known. From our data and those of others $(6,7,12)$ we conclude that the single recording of lead $\mathrm{V}_{4} \mathrm{R}$ in order to see an ST-segment elevation of equal to or more than $1 \mathrm{~mm}$ is the most reliable way to diagnose right ventricular involvement in patients admitted because of an acute inferior myocardial infarction.

\section{Acknowledgement}

We would like to thank Dr. Frans J. Wackers, Department of Internal and Nuclear Medicine, University Hospital, Burlington, Vermont, for his support and advice during the preparation of this manuscript.

\section{References}

\section{Wartman WB, Hellerstein HK:}

The incidence of heart disease in 2000 consecutive autopsies. Amn Intern Med 1948, 28: $41-65$.

2. Wade WG:

The pathogenesis of infarction of the right ventricle. Br Heart $\mathrm{J} 1959,21: 545-54$.

3. John JN, Guiha NH, Broder MI, Limas CJ:

Right ventricular infarction. Clinical and hemodynamic features. Am J Cardiol 1974, 33: $209-14$.

4. Sharpe DN, Botvinick EH, Shames DM, Schiller NB, Massie BM, Chatterjee K, Parmley WW:

The noninvasive diagnosis of right ventricular infarction. Circulation 1978, 57; 483-90.

5. Wackers FJ, Lie KI, Sokole EB, Res J, van der Schoot JB, Durrer D:

Prevalence of right ventricular involvement in inferior wall infarction assessed with myocardial imaging with Thallium 201 and Technetium $99 \mathrm{~m}$ pyrophosphate. Am J Cardiol 1978, 42: 358-62.

6. Erhardt LR, Sjogren A, Wahlberg I:

Single right sided precordial lead in the diagnosis of right ventricular involvement in inferior myocardial infarction. Am Heart $₫ 1976,91: 571-76$. 
7. Candell-Riera J, Figateras J, Valle V, Alvarez A, Gutierrez L, Cortadellas J, Cinca J, Salas A., RHus J:

Right ventricular infarction. Relationships between ST-segment elevation in $V_{4} R$ and hemodynamic scintigraphic and echocardiographic findings in patients with an acute inferior myocardial infarction. Am Heart J 1981, 101: 281-87.

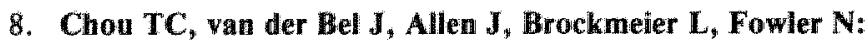

Electrocardiographic diagnosis of right ventricular infarction. Am J Med 1981, 70: 1175-80.

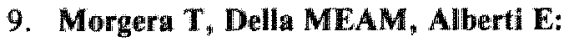

Electrocardiographic diagnosis of right wentricular infarction. Eur Heart J 19812 suppl. A 212 (abstract).

10. Lorell B, Leinbach RC, Pohost GM, Gold HK, Dinsmore RE, Hutter AM, Pastore JO, Desanctiss RW:

Right ventricular infarction: Clinical diagnosis and differentiation from cardiac tamponade and pericardial constriction. Am J Cardiol 1979, 43: 465-71.

11. Braat SH, Brugada P, de Zwaan C, Coenegracht JM, Wellens HJJ:

Value of lead $V_{4} R$ in acute inferior wall infarction to identify right ventricular involvement and risk of development of atrio ventricular nodal block. Am J Cardiol 1982, 49: 998 (abstract).

12. Croft CH, Nïcod P, Corbett JR, Lewis SE, Huxley R, Mukharji J, Willerson JT, Rude RE:

Detection of acute right ventricular infarction by right precordial electrocardiography. Am J Cardiol 1982, 50; 421-427. 


\section{Chapter 4}

\section{Value or lead $\mathrm{V}_{4} \mathrm{R}$ for recognition of the infarct coronary artery in acute inferior myocardial infarction}

by

Simon H. Braat, MD, Pedro Brugada, MD, Karel den Dulk, MD, Vincent van Ommen, MD, Hein J.J. Wellens, MD. Department of Cardiology, University of Limburg, Annadal Hospital, Maastricht, The Netherlands

Published in the American Journal of Cardiology 1984, 53: 1538-1541. 


\section{Summary}

In 84 patients with an acute inferior wall myocardial infarction (MI) admitted within 10 hours after the onset of chest pain a right precordial lead $V_{4} R$ was recorded in addition to the standard 12-lead ECG. The presence or absence of ST-segment elevation in lead $\mathrm{V}_{4} \mathrm{R}$ during the acute phase of $\mathrm{MI}$ was correlated with results of coronary angiography, 2-26 (mean 10) weeks after the acute infarction. Patients were divided into those with a critical stenosis or occlusion proximal (27 patients) or distal ( 36 patients) to the right ventricular branch of the right coronary artery (RCA) or in the circumflex coronary artery (CA) (21 patients). The presence of STsegment elevation $\gtrsim 1 \mathrm{~mm}$ in lead $\mathrm{V}_{4} \mathrm{R}$ has a sensitivity of $100 \%$ and a specificity of $87 \%$ for occlusion of the RCA above the level of the first branch to the right ventricle, while its predictive accuracy is $92 \%$. In contrast, 7 out of 36 patients with a distal occlusion of the RCA showed ST-segment elevation $\geqq 1 \mathrm{~mm}$ in lead $V_{4} R$ ( $p<0.001$ ). None of 21 patients with occlusion of the CA had ST-elevation in $V_{4} R$. The absence of ST-segment elevation $\geqq 1 \mathrm{~mm}$ in lead $V_{4} R$ appears to exclude proximal occlusion of the RCA. Therefore, recording of right precordial lead $V_{4} R$ within 10 hours after onset of acute inferior wall $\mathrm{MI}$ provides a reliable and simple means to predict the location and level of occlusion in the infarct vessel. These findings are of clinical relevance when emergency procedures (intracoronary streptokinase infusion, balloon dilatation, emergency surgery) are considered.

Since Cohn et al (1) described the syndrome of predominant right ventricular dysfunction in the setting of an acute inferior wall myocardial infarction (MI) the interest of recognizing right ventricular infarction (RVI) with non-invasive techniques has grown. The reason being the therapeutic implications of separating patients in those with right ventricular dysfunction and those with the more usual clinical presentation of left ventricular dysfunction. Electrocardiographic diagnosis of RVI using right precordial leads has been correlated with autopsy, scintigraphic, echo-cardiographic and hemodynamic data (2-7). ST-segment elevation $\geq 1 \mathrm{~mm}$ in right precordial lead $V_{4} \mathbb{R}(2-6)$ was found as the best electrocardiographic predictor of RVI in the setting of an acute inferior MI. RVI in the setting of an acute inferior wall $\mathrm{MI}$ is believed to occur when the RCA is severely stenosed or occluded proximal to the branch to the right ventricle. However, inferior wall MI may also occur secondary to occlusion of the circumflex coronary artery (CA). In the latter situation RVI is not expected. In the present study coronary angiograms of patients with a documented inferior wall MI are correlated with data from the unipolar right precordial lead $V_{4} R$ at the time of the acute MI. The purpose of study was to assess the value of $V_{4} R$ in identifying both the level and site of right coronary artery (RCA) or CA occlusion and the presence or absence of RVI. 


\section{Patients and methods}

The patients including had to fulfill the following entrance criteria:

I. admission to the coronary care unit within 10 hours after the onset of chest pain

II. no history or documentation of a previous inferior wall MI

III. presence of an acute inferior wall MI. The diagnosis of MI was based on clinical history, characteristic enzyme pattern and evolutionary ECG changes with the appearance of pathologic Q-waves in the inferior leads

IV. no reinfarction before this catheterisation

$V$. young males ( 40 years) or recurrence of chest pain in spite of medical treatment.

Eighty-eight patients fulfilled these criteria. Ages ranged from 33-71 (mean 55) years. In 79 patients there was no documented myocardial infarction in the past and 9 had already suffered from an anterior wall MI. A standard 12-lead ECG and a right sided chest lead $V_{4} R$ was taken on admission and afterwards every 8 hours during 3 days. ECG's were interpreted by two cardiologists and ST-segment elevation $\geq 1 \mathrm{~mm}$ in $\mathrm{V}_{4} \mathrm{R}$ on admission was judged to be a positive sign for RVI (2-6). Venous blood samples for serum glutamic oxaloacetic transaminase and creatinephosphokinase were drawn on admission and every 8 hours during 3 days and thereafter daily for 2 days. A coronary angiograms was performed 2 to 26 weeks (mean 10) after the acute MI. Reasons for catheterisation were: MI in young males ( $\leqq 40$ years) and recurrence of chest pain in spite of medical treatment in the remaining patients.

A left ventriculography was performed in the right and left anterior oblique projection. Right and left coronary artery angiography was performed using multiple views, including angulated projections. $A \geq 50 \%$ reduction in the luminal diameter of a coronary artery was considered significant. The coronary angiograms were judged by two cardiologists without knowledge of the electrocardiographic findings. Differences in opinion were resolved by discussion. If the RCA and the CA were both diseased, the artery with the subtotall luminal narrowing or a total obstruction was believed to be the cause of the MI.

\section{Results (Table 1)}

On admission 36 out of 88 patients ( $43 \%$ ) had ST-segment elevation $\geq \mathbb{1 m m}$ in lead $V_{4} R$. Two patients of this group showed initially signs of right sided heart failure. 
Table 1

Presence or absence of ST-segment elevation in $V_{4} R \geqq 1 \mathrm{~mm}$ and the site and degree of lesions in the coronary arteries of the 88 patients studied

\begin{tabular}{|c|c|c|c|c|c|c|}
\hline No. & Age & $\mathbf{V}_{4} \mathbf{R}$ & $\mathbf{R C A}$ & LAD & CA & \\
\hline$\rrbracket$ & 61 & $\mathrm{~N}$ & 95 & 75 & & \\
\hline 2 & 43 & $N$ & & & 75 & \\
\hline 3 & $\$ 2$ & $\mathrm{~N}$ & & 60 & 75 & \\
\hline 4 & 51 & pos & 100 & 100 & & * \\
\hline 5 & 70 & pos & 95 & & & \\
\hline 6 & 62 & $N$ & & & 100 & \\
\hline 7 & 49 & pos & 100 prox & 70 & & \\
\hline 8 & 42 & pos & 100 prox & 75 & & \\
\hline 9 & 67 & pos & 100 prox & 90 & & \\
\hline 10 & 54 & $\mathrm{~N}$ & 75 & 50 & & \\
\hline 11 & 48 & $\mathrm{~N}$ & 95 & 95 & 75 & * \\
\hline 12 & 66 & pos & 95 & 80 & 50 & \\
\hline 13 & 59 & pos & 100 prox & 90 & & \\
\hline 14 & 48 & $\mathrm{~N}$ & 100 & 75 & & \\
\hline 15 & 57 & $\mathrm{~N}$ & 90 & 80 & 80 & \\
\hline 16 & 54 & pos & 100 & 100 & & \\
\hline 17 & 52 & pos & 100 & 100 & 80 & * \\
\hline 18 & 41 & pos & 100 prox & 75 & 90 & \\
\hline 19 & 47 & $\mathrm{~N}$ & 100 & 70 & & \\
\hline 20 & 62 & pos & 100 & 80 & 80 & \\
\hline 21 & 63 & $\mathrm{~N}$ & & & 99 & \\
\hline 22 & 59 & pos & 100 prox & 50 & & \\
\hline 23 & 53 & pos & 90 prox & 70 & & \\
\hline 24 & 42 & $\mathrm{~N}$ & 95 & & 90 & \\
\hline 25 & 71 & $\mathbf{N}$ & 75 & 75 & 90 & \\
\hline 26 & 33 & $\mathbf{N}$ & & 90 & 99 & \\
\hline 27 & 60 & $\mathrm{~N}$ & 95 & & & \\
\hline 28 & 67 & $\mathbf{N}$ & 100 & 50 & 99 & * \\
\hline 29 & 54 & $\mathrm{~N}$ & 100 & & & \\
\hline 30 & 41 & $\mathrm{~N}$ & & 60 & 100 & \\
\hline 31 & 38 & pos & 100 prox & & & \\
\hline 32 & 62 & $\mathrm{~N}$ & 100 & 70 & & \\
\hline 33 & 55 & $\mathrm{~N}$ & 75 & 80 & & \\
\hline 34 & 42 & pos & 100 prox & 90 & 80 & \\
\hline
\end{tabular}




\begin{tabular}{|c|c|c|c|c|c|c|}
\hline No. & Age & $\mathbf{V}_{4} \mathbf{R}$ & $\mathbf{R C A}$ & $\mathbf{L A D}$ & $\mathrm{CA}$ & \\
\hline 35 & 62 & $\mathbf{N}$ & & 60 & 100 & \\
\hline 36 & 62 & pos & 90 prox & & & \\
\hline 37 & 43 & $\mathrm{~N}$ & 100 & 75 & 60 & \\
\hline 38 & 62 & $\mathbf{N}$ & 100 & 100 & 80 & $*$ \\
\hline 39 & 57 & $\mathrm{~N}$ & & 50 & 90 & \\
\hline 40 & 56 & $N$ & 70 & 60 & 95 & \\
\hline 41 & 71 & $\mathrm{~N}$ & 95 & & & \\
\hline 42 & 53 & $\mathrm{~N}$ & 100 & 60 & 100 & $*$ \\
\hline 43 & 33 & pos & 100 prox & 60 & & \\
\hline 44 & 54 & $\mathrm{~N}$ & 100 & 75 & 75 & \\
\hline 45 & 39 & $N$ & & 80 & 85 & \\
\hline 46 & 45 & $\mathrm{~N}$ & 80 & & & \\
\hline 47 & 39 & pos & 100 prox & & & \\
\hline 48 & 62 & pos & 75 & 95 & 75 & * 0 \\
\hline 49 & 50 & pos & 100 prox & 80 & 80 & \\
\hline 50 & 46 & $\mathrm{~N}$ & & & 95 & \\
\hline 51 & 46 & pos & 100 prox & 90 & & \\
\hline 52 & 60 & $\mathrm{~N}$ & & 70 & 80 & \\
\hline 53 & 38 & $\mathrm{~N}$ & 100 & & & \\
\hline 54 & 59 & $\mathrm{~N}$ & 80 & 95 & 100 & \\
\hline 55 & 54 & $\mathrm{~N}$ & & & 100 & \\
\hline 56 & 66 & pos & 90 prox & 95 & & \\
\hline 57 & 59 & $\mathrm{~N}$ & 80 & 70 & 100 & \\
\hline 58 & 60 & $\mathbf{N}$ & 100 & 80 & & \\
\hline 59 & 44 & pos & 80 & 60 & 80 & $*$ \\
\hline 60 & 69 & $N$ & & 50 & 95 & \\
\hline 61 & 63 & $\mathrm{~N}$ & 100 & 60 & 70 & \\
\hline 62 & 57 & $\mathrm{~N}$ & & & 100 & \\
\hline 63 & 53 & pos & 100 prox & 60 & & \\
\hline 64 & 62 & $\mathrm{~N}$ & 95 & 70 & 50 & \\
\hline 65 & 56 & $\mathrm{~N}$ & 100 & 90 & 70 & \\
\hline 66 & 60 & pos & 100 prox & 70 & 80 & \\
\hline 67 & 40 & $\mathrm{~N}$ & & 80 & 100 & \\
\hline 68 & 64 & $\mathbb{N}$ & 100 & 85 & & \\
\hline 69 & 54 & $\mathbf{N}$ & & & 100 & \\
\hline 70 & 65 & $N$ & 100 & & & \\
\hline 71 & 64 & $\mathrm{~N}$ & 80 & 75 & 95 & \\
\hline 72 & 59 & pos & 100 prox & 80 & & \\
\hline 73 & 54 & pos & 100 prox & 80 & 75 & \\
\hline
\end{tabular}




\begin{tabular}{llllll} 
No. & Age & $\mathbf{V}_{4} R$ & RCA & LAD & CA \\
$\mathbf{7 4}$ & 52 & $\mathrm{~N}$ & 80 & 75 & $\mathbf{1 0 0}$ \\
$\mathbf{7 5}$ & 60 & pos & $\mathbf{1 0 0}$ prox & & \\
76 & 59 & $\mathrm{~N}$ & $\mathbf{1 0 0}$ & 90 & 80 \\
77 & 47 & pos & $\mathbf{1 0 0}$ prox & & \\
78 & 51 & $\mathrm{~N}$ & 60 & 75 & $\mathbf{1 0 0}$ \\
79 & 70 & pos & $\mathbf{1 0 0}$ prox & 80 & \\
80 & 55 & $\mathrm{~N}$ & $\mathbf{1 0 0}$ & 90 & 90 \\
81 & 53 & pos & $\mathbf{1 0 0}$ prox & 60 & \\
82 & 53 & pos & $\mathbf{1 0 0}$ & 80 & \\
83 & 58 & $\mathrm{~N}$ & & 60 & $\mathbf{1 0 0}$ \\
84 & 65 & pos & $\mathbf{1 0 0}$ prox & 70 & \\
85 & 63 & pos & $\mathbf{1 0 0}$ prox & & \\
86 & 66 & $\mathrm{~N}$ & $\mathbf{1 0 0}$ & 60 & 80 \\
87 & 54 & pos & $\mathbf{1 0 0}$ prox & 80 & 60 \\
88 & 50 & pos & $\mathbf{1 0 0}$ prox & & \\
\hline
\end{tabular}

* Previous anterior wall infarction.

0 Impossible to judge which stenosis causes the infarction.

The bold-faced numbers indicate the coronary artery judged to be the cause of the myocardial infarction.

Abbreviations: prox $=$ occlusion proximal to the first branch to the right ventricle; RCA = right coronary artery; $\mathrm{LAD}=$ left anterior descending coronary artery; $\mathrm{CA}=$ circumflex coronary artery; $N=$ no elevation in $V_{4} R_{;} ;$pos $=S T$ elevation $\geq 1 \mathrm{~mm}$ in $V_{4} R$.

\section{Catheterisation data:}

Twenty-one patients had single vessel disease, in 14 patients only the RCA and in 7 cases only the CA was affected. Two vessel disease was found in 35 patients, in 24 cases the RCA and the left anterior descendens (LAD) and in 10 the CA and the LAD. Only 1 patient had simultaneous significant luminal narrowing of the RCA and the CA. In 32 patients three vessel disease was found. In 4 patients of the group with three vessel disease the stenosis in the RCA as well as in the CA was so severe, that it was impossible to judge which stenosis had caused the MI. These 4 patients are therefore not included in the correlation data of catheterisation and electrocardiographic recordings. This leaves 84 patients for analysis. In $68 \%$ (57 out of 84 patients) a complete occlusion of at least one coronary artery was present. In 20 patients (24\%) a stenosis between 90 and $95 \%$ was found and in 7 patients (8\%) a narrowing between 75 and $90 \%$ was found and considered to be the cause for the MI. No patient in this study was found to have normal coronary arteries. 
For correlation with the ECG findings we divided the site of coronary artery stenosis in patients in whom it was possible to judge which coronary artery has caused the inferior wall MI (84 patients), in three groups:

a. stenosis proximal to the first branch to the right ventricle;

b. distal to the branch of the right ventricle; or

c. in the CA.

On comparing the electrocardiographic findings of lead $V_{4} R$ with the catheterisation findings, we found that none of the 21 patients with CA stenosis had ST-segment ellevation in lead $\mathrm{V}_{4} \mathrm{R}$. All 27 patients in whom the stenosis was located above the first branch to the right ventricle, had ST-segment elevation of more than $1 \mathrm{~mm}$ in lead $V_{4} R$ (Table 2). From the group of 36 patients in whom the stenosis was located below the first branch to the right ventricle 7 showed ST-segment elevation in $V_{4} R$, while that was absent in 29 patients. Of these 7 patients, 3 had three vessel disease, 3 two vessel disease and 1 single vessel disease.

\section{Table 2}

Presence and absence of ST-segment elevation in lead $V_{4} R \geq 1 \mathrm{~mm}$ and site of occlusion in coronary artery

Occlusion of the RCA above the first branch to the right ventricle $\mathrm{N}=27$

$$
\mathbf{V}_{4} \mathbf{R}+\mathbf{V}_{4} \mathbf{R}-
$$

Occlusion of the RCA distal to the first branch to the right ventricle $\mathrm{N}=36$

Occlusion of the circumflex coronary artery

Abbreviations: $\mathrm{RCA}=$ right coronary artery

The sensitivity of ST-segment elevation in lead $\mathrm{V}_{4} \mathrm{R}$ to predict an occlusion above the first branch to the right ventricle is $100 \%$, the specificity in this group is $87 \%$, while the predictive accuracy is $92 \%$.

\section{Discussion}

Several studies have demonstrated the value of $S T$-segment elevation in lead $V_{4} R$ for diagnosing RVI in patients with inferior wall MI (2-6). Inwolvement of the right ventricle has been demonstrated in these patients by pathological (2), scintigraphic $(3,4,5)$ and hemodynamic studies $(6)$. Inferior wall MI can occur in relation to oc- 
clusion of the RCA or CA, but blood supply to the free wall of the right ventricle occurs in more than $90 \%$ of patients by way of a branch of the RCA $(8,9)$. One would therefore expect that the electrocardiographic evidence for RVI (ST-elevation in lead $V_{4} R$ ) would also have a high sensitivity and specificity to identify occlusion of the RCA. The results of our study (Table 2) show that ST-segment elevation of $\geq 1 \mathrm{~mm}$ in lead $V_{4} R$ in patients with acute inferior MI has a sensitivity of $100 \%$ and a specificity of $87 \%$ for a stenosis proximal to the branch of the right ventricle of the RCA, the predictive accuracy is $92 \%$. Seven out of 36 patients with a distal occlusion of the RCA showed ST-segment elevation of $\geqq 1 \mathrm{~mm}$ in lead $V_{4} \mathbb{R}$. In patients with inferior wall $\mathrm{MI}$ and occlusion distal to the first branch to the right ventricle of the RCA, ST-segment elevation in lead $V_{4} R$ could indicate involvement of the right ventricle by occlusion of the 2 nd and 3 rd right ventricular branch of the RCA to the right ventricle. Absence of ST-segment elevation in lead $V_{4} R$ in patients with acute inferior wall $\mathrm{MI}$ is, however, of no help to identify RCA or CA involvement, but excludes proximal occlusion of the RCA.

Our study was retrospective and the patient population was selected. In our department we do not routinely catheterize all patients after MI, but only those patients presenting a particular diagnostic, prognostic or therapeutic problem. Our prevalences of total or subtotal occlusion of the coronary arteries was however similar to the prevalences, found in unselected patients catheterized 1 month post-MI (10).

\section{Clinical implications:}

Our results may have clinical implications for patients with an acute MI. Patients with unstable angina pectoris or acute MI are presently being more aggressively treated than in the past. Several centers are performing studies on the value of intracoronary thrombolysis with streptokinase, balloon dilatation of coronary arteries and bypass surgery. Knowledge about the site of obstruction in the coronary arteries can expedite some of these procedures. The simple recording of lead $V_{4} R$ in patients with acute inferior wall MI can give rapid information about occlusion of the RCA (ST elevation in lead $\mathrm{V}_{4} \mathrm{R} \geq 1 \mathrm{~mm}$ ) and help to exclude proximal occlusion. As previously discussed $(3,11) \mathrm{ST}$-segment elevation disappeares rapidly in patients with inferior wall MI, 50\% disappeared within within 10 hours (3). Therefore, electrocar diographic recordings should be made as soon as possible after admission. In our department recording of right precordial leads in patients admitted with inferior MI has become a routine procedure.

\section{References}

1. Cohn JN, Guiha NH, Broder MI, Limas CJ:

Right ventricular infarction. Clinical and hemodynamic features. Am J Cardiol 1974, 33: 209-214 
2. Erhardt LR, Sjogren A, Wahlberg I:

Single right sided precordial lead in the diagnosis of right ventricular involvement in inferior yocardial infarction. Am Heart J 1976, 91: 571-571

3. Braat SH, Brugada P, de Zwaan C, Coenegracht JM, Wellens HJJ:

Value of electrocardiogram in diagnosing right ventricular involvement in patients with an acute inferior wall myocardial infarction. $\mathrm{Br}$ Heart J 1983, 49: 368-372

4. Croft CH, Nicod P, Corbett JR, Lewis SE, Huxley R, Mukharji J, Willerson IT, Rude RE:

Detection of acute right ventricular infarction by right precordial electrocardiography. Am J Cardiol 1982, 50: 421-427

5. Klein HO, Tordjman T, Ninio R, Sareli P, Oren V, Lang R, Gefen J, Pauzner C, Segni ED, David D, Kaplinsky E:

The early recognition of right ventricular infarction: Diagnostic accuracy of the electrocardiographic $V_{4} R$ lead. Circulation 1983: 67: 558-565

6. Candell-Riera J, Figueras J, Valle V, Alvarez A, Gutierrez L, Cortadellas J, Cinca J, Salas A, Rias J:

Right ventricular infarction: Relationships between $S T$-segment elevation in $V_{4} R$ and hemodynamic scintigraphic and echocardiographic findings in patients with acute inferior myocardial infarction. Am Heart J 1981, 101: 281-287

7. Chou TC, Van der Bel-Kahn J, Allen J, Brockmeier L, Fowler NO:

Electrocardiographic diagnosis of right ventricular infarction. Am J Med 1981, 70: $1175-1180$

8. James T:

Anatomy of the coronary arteries. New York, Paul D. Hoeber 1961, 51-60

9. Isner JM, Roberts WC:

Right ventricular infarction complicating left ventricular infarction secondary to coronary heart disease. Frequency, location, associated findings and significance from analysis of 236 necropsy patients with acute or healed myocardial infarction. Am J Cardiol 1978, 42: 885-894

10. Betriu A, Castaner A, Sanz GA, Pare JC, Roig E, Coll S, Magrina J, Navarro-Lopez F: Angiographic findings 1 month after myocardial infarction: A prospective study of 259 survivors. Circulation 1982, 65: 1099-1105

11. Braat SH, Brugada P, de Zwaan C, Coenegracht JM, Wellens HJJ:

Value of lead $V_{4} R$ in acute inferior wall infarction to identify right ventricular involvement and risk of development of AV nodal block. Am Heart J 1984, 107: $1183-1186$. 



\section{Chapter 5}

\section{Intracoronary thrombolysis for acute}

myocardial infarction late after bypass surgery: value of lead $\mathrm{V}_{4} \mathrm{R}$

by

Simon H. Braat, MD, Karel den Dulk, MD and

Hein J.J. Wellens, MD. Department of Cardiology, University of Limburg, Annadal Hospital, Maastricht, The Netherlands

Published in the American Journal of Cardiology 1984, 53: 637-639. 


\section{Case report}

Lysis of intracoronary thrombi in the acute stage of myocardial infarction (MI) can be effectively achieved by administration of thrombolytic agents in $60-85 \%$ of patients when it is given within 6 hours after the onset of chest pain (1-3). We recently studied a patient admitted because of an acute $\mathrm{MI}$ in whom coronary bypass surgery had been performed 5 years earlier. The recording of lead $V_{4} R$ was of great help in recognizing the occluded vessels.

A 60 year old man was admitted because of chest pain not reacting to nitroglycerin and nifedipine sublingually. He had had angina for 10 years, with bypass surgery at age 55 . The catheterisation findings before bypass surgery showed a proximal occlusion in a dominant right coronary artery which was filled retrogradely by the left anterior descending (LAD) artery. The LAD artery showed a $85 \%$ diameter reduction just after the first diagonal branch, there was a $75 \%$ stenosis at the origin of the first obtuse marginal (OM) branch of the circumflex coronary artery (CA). A small infero-apical aneurysm was found on left ventricular angiography. Coronary bypass graft surgery was performed with 1 graft to the right coronary artery, 1 to the LAD and 1 to the first OM branch. The postoperative period was uneventful and following operation the patient was free of complaints until the present admission.

Blood pressure was $130 / 80 \mathrm{mmHg}$, the pulse rate 95 beats/minute. A fourth heart sound was present. The electrocardiogram on admission showed signs of an acute infero-posterior wall MI (Fig. 1). Lead $V_{4} R$ showed ST-segment elevation of $1 \mathrm{~mm}$ indicating ischemia of the right ventricle $(4,5)$.

Since the patient was admitted 1 hour after the onset of chest pain streptokinase was started 100,000 IU intravenously. Because of the ST-segment elevation in lead $V_{4} R$ we suspected ischemia of the right ventricle and therefore problems in the graft to the right coronary artery and not in the one to the OM branch of the CA. Using the Judkins technique a catheter was introduced in the right coronary artery bypass graft. This bypass was found to be proximally occluded (Fig. 2A). After 200,000 IU of streptokinase the artery opened up (Fig. 2B) and immediately the pain and ST-segment elevation in II, $I I I$ and AVF and in $V_{4}$ R disappeared (Fig. 3). We then proceeded with the catheterization. The 2 other bypasses were patent. The left coronary artery showed the same abnormalities as 5 years earlier. 


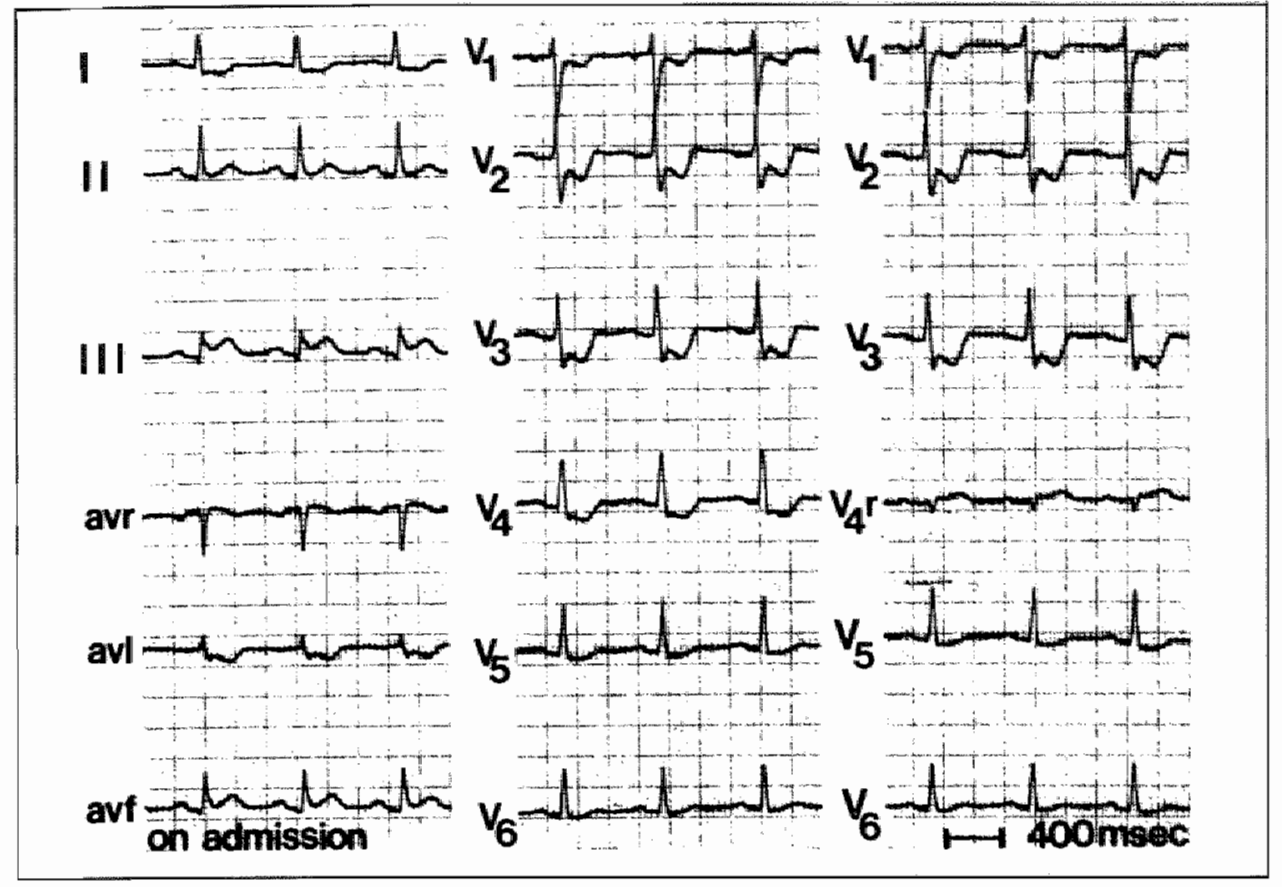

Figure 1 The 12 lead electrocardiogram shows an acute infero-posterior wall myocardial infarction. ST-segment elevation of $1 \mathrm{~mm}$ is present in lead $\mathrm{V}_{4} \mathrm{R}$.
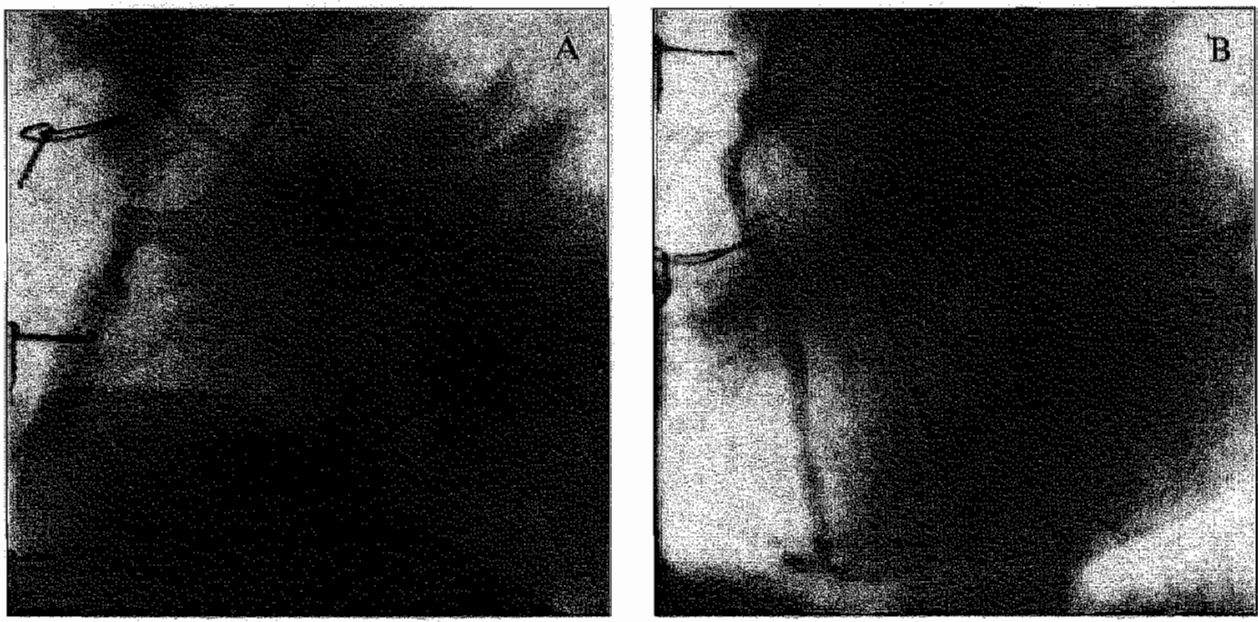

Figure 2. A. Before streptokinase angiography of the bypass to the right coronary artery shows complete occlusion.

B. After streptokinase distal filling of the bypass is present with visualization of the right coronary artery. An $80 \%$ stenosis is visible in the bypass graft. 


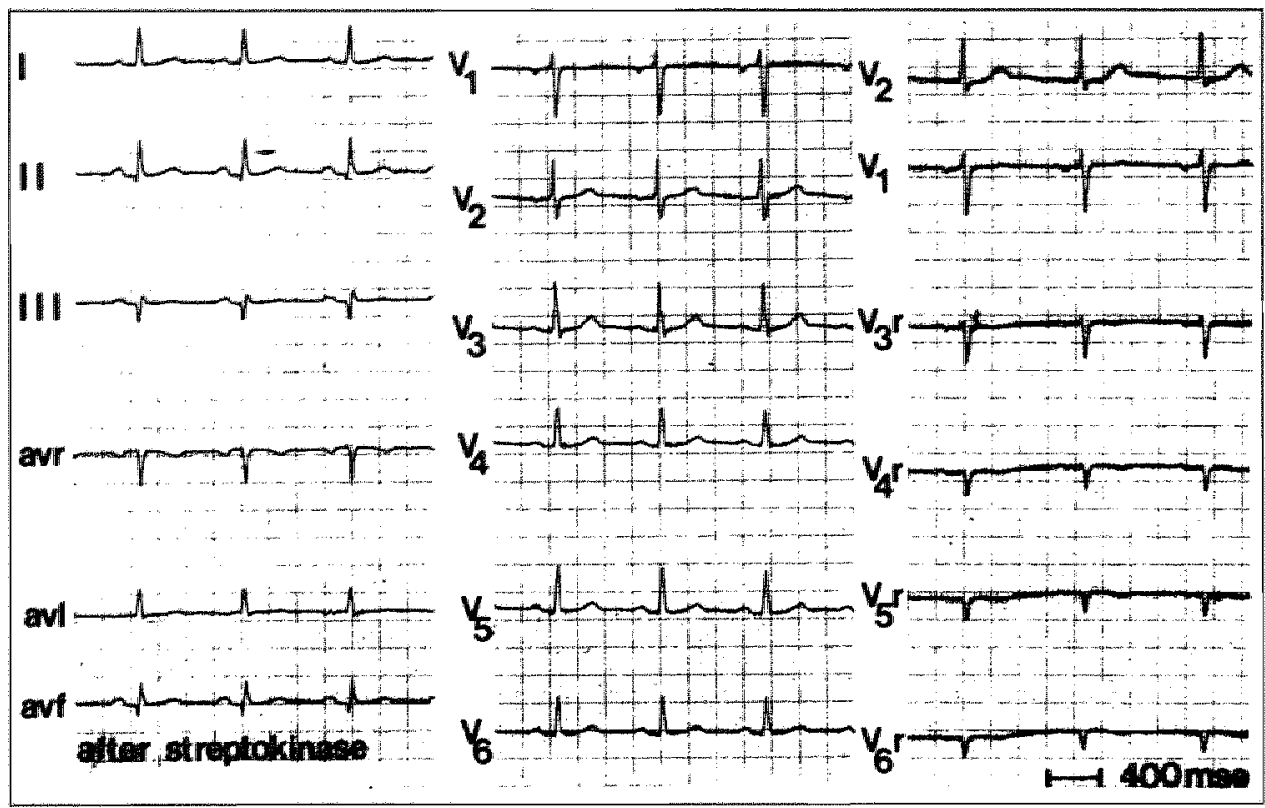

Figure 3 Electrocardiogram recorded after streptokinase infusion. The signs of the acute infero-posterior wall myocardial infarction have disappeared. ST-segment elevation in lead $V_{4} R$ is no longer present.

The ECG returned to the one during his last out-patient clinic visit. There was only a slight enzyme rise. The maximal creatine phosphokinase value became 360 (normal value $\leqq 240$ ) IU.

The recording of lead $\mathrm{V}_{4} \mathrm{R}$ can be of importance in deciding which coronary artery system should be investigated first for streptokinase therapy. Five years ago in our patient the right coronary artery was occluded. Thus, we believed that the bypass on the right coronary artery had to be occluded and the artery was immediately infused with streptokinase. We and other investigators $(4,5)$ have shown that in patients with an acute inferior wall MI ST elevation of $\geqq 1 \mathrm{~mm}$ in lead $V_{4} R$ very strongly suggests involvement of the right ventricle with proximal occlusion of the right coronary artery. In almost $90 \%$ the blood supply to the right ventricle is coming from the right coronary artery and in $10 \%$ from the LAD (6). When our patient presented with an acute inferior wall MI with the information of having bypass grafts to a proximally occluded right coronary artery and a proximally narrowed $O M$ branch of the CA the ST-segment elevation in lead $V_{4} R$ indicated to us a perfusion problem in the right coronary artery. Therefore, we immediately directed our attention to the bypass graft on the right coronary artery which indeed 
was found to be occluded. In the setting of an acute inferior wall MI, when no STsegment elevation is seen in the right precordial lead $V_{4} R$, the probability of an occlusion of the $\mathrm{CA}$ or the right coronary artery is almost equal. Non-invasive methods should be found to make it possible to distinguish between a perfusion problem in the right from one in the CA in these patients.

\section{References}

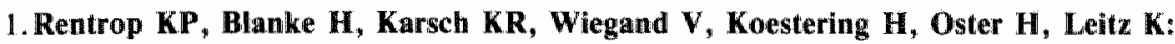
Acute myocardial infarction: intracoronary application of nitroglycerin and streptokinase. Clin Cardiol 1979: 2, 354-63.

2. Ganz W, Buchbinder N, Marcus H, Mondkar A, Maddahi J, Charwzi $\mathbf{Y}$, O'Connor L, Shell W, Fishbein M, Kass R, Miyamoto A, Swan HJC:

Intracoronary thrombolysis in evolving myocardial infarction. Am Heart J 1981: 101, 4-13.

3. Mathey DG, Kuck K-H, Tilsner V, Krebber H-J, Bleifeld W:

Non-surgical coronary artery recanalization in acute transmural myocardial infarction. Circulation 1981: 63, 489-97.

4. Erhard LR, Sjögren A, Wahlberg I:

Single right-sided precordial lead in the diagnosis of right ventricular involvement in inferior myocardial infarction. Am Heart J 91: 571-576, 1976.

5.Braat SH, Brugada P, de Zwaan C, Coenegracht JM, Wellens HJJ:

Value of electrocardiogram in diagnosing right ventricular involvement in patients with an acute inferior wall myocardial infarction. Brit Heart J 1983: 49, 368-72.

\section{James TN:}

The arteries of the free ventricular wall in man. Anat Rec 136: 371-384, 1960. 



\section{Chapter 6}

\section{Value of lead $\mathrm{V}_{4} \mathrm{R}$ in exercise testing to predict proximal stenosis of the right coronary artery}

by

Simon H. Braat, MD, J. Herre Kingma, MD, Pedro Brugada, MD, Hein J.J. Wellens, MD. Department of Cardiology, University of Limburg, Annadal Hospital, The Netherlands

Submitted for publication: American Journal of Cardiology 


\section{Summary}

To assess the value of lead $V_{4} R$ during exercise testing to predict proximal stenosis of the right coronary artery 107 patients were studied. In all patients a Bruce exercise test with the simultaneous recording of leads $I, I I, V_{4} R, V_{1}, V_{4}$ and $V_{6}$ was followed by coronary angiography. Apart from registering ST-segment changes in the conwentional leads, all patients were classified according to absence or presence of an ST-segment deviation of $\geqq 1 \mathrm{~mm}$ in lead $V_{4} R$. Seventy-nine of the 107 patients were studied because of inadequate control of angina pectoris. Seven patients had suffered from a myocardial infarction under age 40 . Twenty-one patients were analysed because of severe cardiac arrhythmias. In the 46 patients who previously had a myocardial infarction, the infarct location was inferior in 28 and anterior in 18 . Seven of the 14 patients without myocardial infarction and a significant stenosis proximal in the right coronary artery showed during exercise ST-segment deviation $\geq 1 \mathrm{~mm}$ in lead $V_{4} R$. This was also observed in 11 of 18 patients with an old inferior wall infarction and a proximal occlusion of the right coronary artery. None of the 53 patients without significant stenosis in the right coronary artery showed exercise related ST-segment changes in lead $\mathrm{V}_{4} \mathrm{R}$. Exercise related $\mathrm{ST}$-segment deviation in lead $V_{4} R$ had a sensitivity of $56 \%$, a specificity of $96 \%$ and a predictive accuracy of $84 \%$ in recognizing a proximal stenosis in the right coronary artery. Our observations indicate that the recording of lead $V_{4} R$ during exercise is of value to predict or exclude proximal stenosis in the right coronary artery.

In 1950 Master (1) popularized the 2 step exercise test. In 1957 Bruce and Hornsten (2) introduced high-performance treadmill exercise testing for the detection and evaluation of coronary artery disease. In the last decade, several reports $(3,4)$ showed that the value of the exercise test can be improved by adding the analysis of other variables to the electrocardiographic changes during exercise. Further improwement in the walue of electrocardiographic detection of ischaemia can be achieved by using multiple electrocardiographic leads (5). The presence of STsegment elevation in lead $V_{4} R$ in an acute inferior wall myocardial infarction has been shown to be a sensitive and specific sign of right ventricular involvement (6-10). ST-segment elevation in $V_{4} R$ is almost exclusively seen during obstruction of the right coronary artery proximal to the first branch to the right ventricle (11). The purpose of this study was to assess the value of changes in lead $V_{4} R$ during exercise stress testing to predict proximal stenosis in the right coronary artery. 


\section{Methods:}

\section{Patient population}

One hundred and seven consecutive patients admitted for coronary angiography were studied. In 79 patients chest pain with inadequate reaction to anti-anginal medication was present. Seven patients were below the age of 40 and had suffered a myocardial infarction. Twenty-one patients were analysed because of severe rhythm disturbances. There were 18 women and $89 \mathrm{men}$. Age ranged between 27 and 72 (mean $54 \pm 10$ ) years. All patients with chest pain were receiving long acting nitroglycerine, a calcium channel blocking agent and a B-blocking agent. No patient had signs of the Wolff-Parkinson-White syndrome, left ventricular hypertrophy or bundle branch block. Forty-six patients had sustained a previous myocardial infarction, 18 anterior and 28 an inferior wall myocardial infarction.

\section{Exercise testing}

None of the patients had evidence of impending or healing myocardial infarction or an acute general illness. Six electrocardiographic leads (I, II, $V_{4} R, V_{1}, V_{4}$ and $V_{6}$ ) were recorded simultaneously. $V_{4} R$ was placed on the right chest wall in the midclavicular line in the fifth intercostal space. The arm electrodes were applied in the far lateral aspects of the infraclavicular fossae and a standard electrocardiogram was recorded at rest in the recumbent and standing position and interpreted for contraindications before starting exercise. At the end of each 3-minute exercise stage, the 6 electrocardiographic leads, as mentioned above were recorded and every 60 sec. thereafter for at least 10 minutes or until resolution of any exercise-induced abnormalities. The treadmill protocol of Bruce and Hornsten (2) was used and patients were allowed to touch the front handrail but not to lean or pull on it. Exercise was stopped because of fatigue, shortness of breath, leg discomfort or chest pain with/without ST-segment depression. Achieving the maximal predicted heart rate according to age was no reason to stop exercising.

An ST-T abnormality suggestive of ischernia was defined as ST-T depression of at least $1 \mathrm{~mm}$ and lasting at least $80 \mathrm{~ms}$ after the J-point. In patients with ST-segment deviation in the resting electrocardiogram an additional $1 \mathrm{~mm}$ of ST-T depression was required. In lead $\mathrm{V}_{4} \mathrm{R}$ the same approach was used, but in addition, also STsegment elevation of more than $1 \mathrm{~mm}$ lasting at least $80 \mathrm{~ms}$ after the J-point was noticed. The test was considered negative if there was no ST-segment deviation $\geq$ $1 \mathrm{~mm}$.

Only when $90 \%$ of the age predicted maximal heart rate was achieved the test was considered adequate. Exercise tests were judged independently by two cardiologists and disagreement was resolved by consensus. 


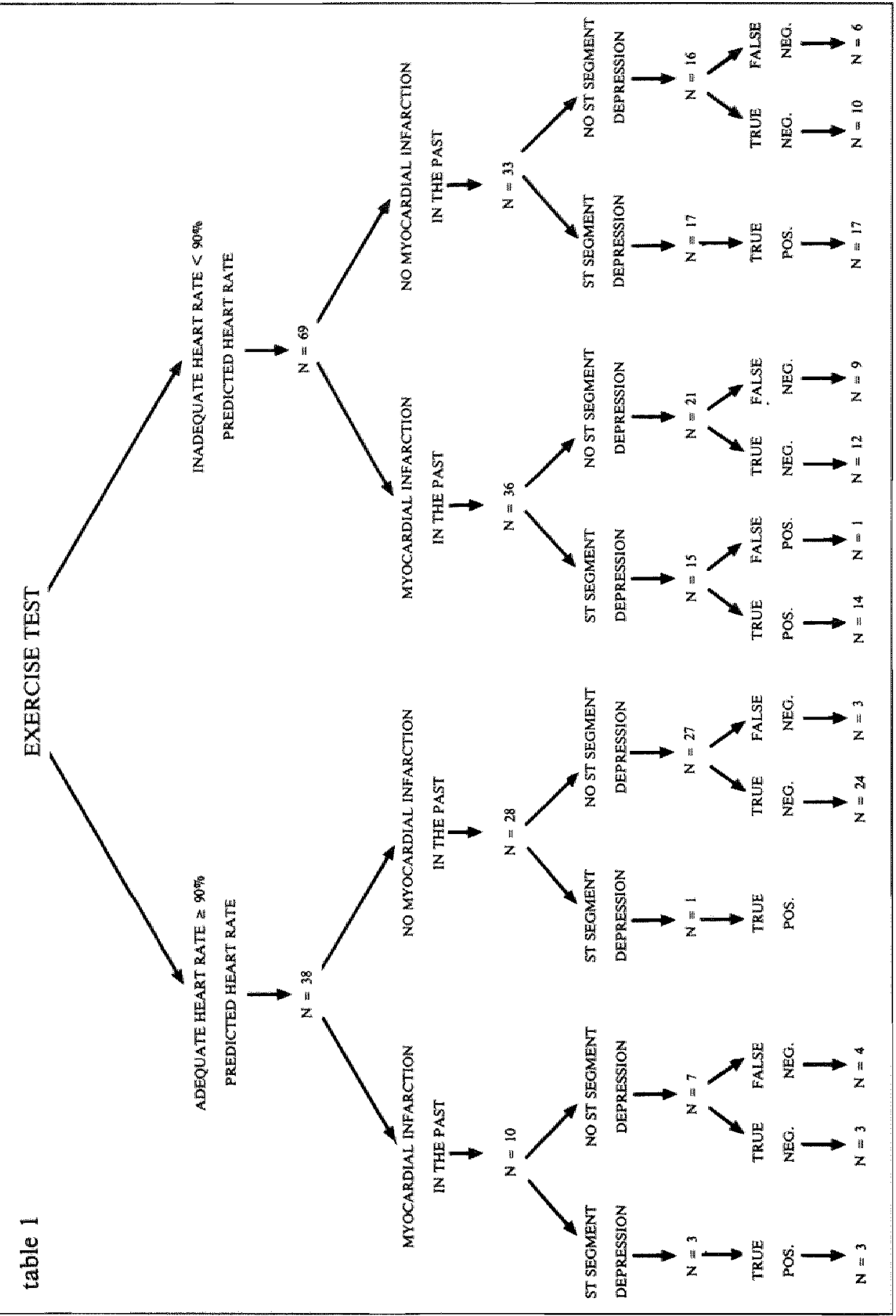




\section{Coronary angiography}

All patients had selective coronary angiography by the Judkins technique (12) within one week after the performance of the exercise test. The coronary arteries were viewed and filmed in multiple and angulated projections. Angiograms were independently interpreted by two cardiologists unaware of the results of the exercise test. Disagreement in judgement was resolved by consensus. A stenosis of more than $50 \%$ was considered to be significant. It was allso noticed if a stenosis in the right coronary artery was located above or below the first branch to the right ventricle.

\section{Results (Table I)}

Thirty-eight patients $(35 \%)$ achieved at least $90 \%$ of the predictive heart rate, 10 of them had previously suffered from a myocardial infarction. Four patients showed ST-segment depression $\geqq 1 \mathrm{~mm}$ in one or more leads, 3 of them had suffered from a myocardial infarction in the past. Of the group of 69 patients who did not achieve $90 \%$ of the predictive heart rate, 32 patients showed ST-segment depression of more than $1 \mathrm{~mm}$ in one or more leads. An old myocardial infarction was present in 15 of these 32 patients. In total 36 patients showed diagnostic ST-segment depression with 18 patients previously having suffered from a myocardial infarction.

\section{Catheterisation data}

Thirty-four patients had normal coronary arteries, 22 patients had single vessel disease; 16 of them had suffered from a myocardial infarction in the past; 25 patients had two vessel disease and 26 patients had three vessel disease.

\section{Correlation between the conventional exercise ECG and catheterisation data}

In the group of patients with single vessel disease and an old myocardial infarction a negative exercise test was considered to be true negative.

In the group of patients with an old myocardial infarction and two or three vessel disease a positive test was considered to be true positive if a significant stenosis was present in a coronary artery other than the infarct vessel. A true positive exercise test was found in 35 patients; a false negative test in 22 patients and a true negative test in 49 patients. One patient had a false positive exercise test.

In the group of 38 patients with an adequate exercise test 4 patients had a ST-

\section{Table 1 Exercise test}

The exercise tests are divided in groups of patients with or without achieving the predicted heart rate and with or without an old myocardial infarction and the numbers of true positive, true negative, false negative and false positive are given. 
segment depression of more than $1 \mathrm{~mm}$ in the presence of significant stenoses. Seven patients of this group had no ST-segment depression, while the coronary angiogram showed significant stenoses, 4 of them had suffered from an old myocardial infarction and had at least two significant stenoses.

Twenty-four patients with an adequate exercise test had normal coronary arteries and had no ST-segment depression of more than $1 \mathrm{~mm}$. Three patients had an old infarction and single vessel disease and had no ST-segment depression. Of the 69 patients with an inadequate exercise test 32 patients showed ST-segment depression and 31 had significant stenoses. Fourteen of these patients had suffered from an infarction in the past. Fifteen of the 69 patients with an inadequate exercise test had no ST-segment deviation of more than $1 \mathrm{~mm}$, while significant stenoses were found in the angiogram. Nine patients of this group had suffered from an infarction in the past and had at least two wessel disease.

In 22 of the 69 patients no ST-segment depression was seen while in 10 patients normal coronary arteries were found. The other 12 patients had an old infarction and single vessel disease.

All 22 were considered to be true negative. One patient with an old inferior wall myocardial infarction and single vessel disease of the right coronary artery and a positive exercise test was considered false positive.

So, based on observations on the conventional ECG leads during exercise, the sensitivity of ST-segment depression $\geqq 1 \mathrm{~mm}$ in all 107 patients to predict significant stenoses is $60 \%$ while the predictive accuracy is $790 \%$.

The sensitivity in the group of patients with an adlequate exercise test is $36 \%$, while the predictive accuracy is $82 \%$. For the group of paiients without an inadequate exercise test the sensitivity is $67 \%$ and the predictive accuracy $78 \%$.

\section{Findings in lead $V_{4} R$}

Eighty-six patients had no ST-segment elevation or depression in $V_{4} R$ of more than $1 \mathrm{~mm}$. In 17 patients ST-segment elevation in $V_{4} R$ of more than $1 \mathrm{~mm}$ was found. In 4 patients we found a significant depression in lead $V_{4} R$.

Table 2 Correlation between the catheterisation data and $V_{4} R$

The coronary angiographic data of the right coronary artery are given. The groups of significant stenoses in the right coronary artery are then divided in patients with or without an old myocardial infarction on the ECG. The end of the table listed the numbers of true positive, true negative, false positive and false negative deviation in $V_{4} R$ to predict proximal stenosis in the right coronary artery. The numbers in parenthesis are the numbers of ST-segment depression in $V_{4} R \geqq 1 \mathrm{~mm}$. 


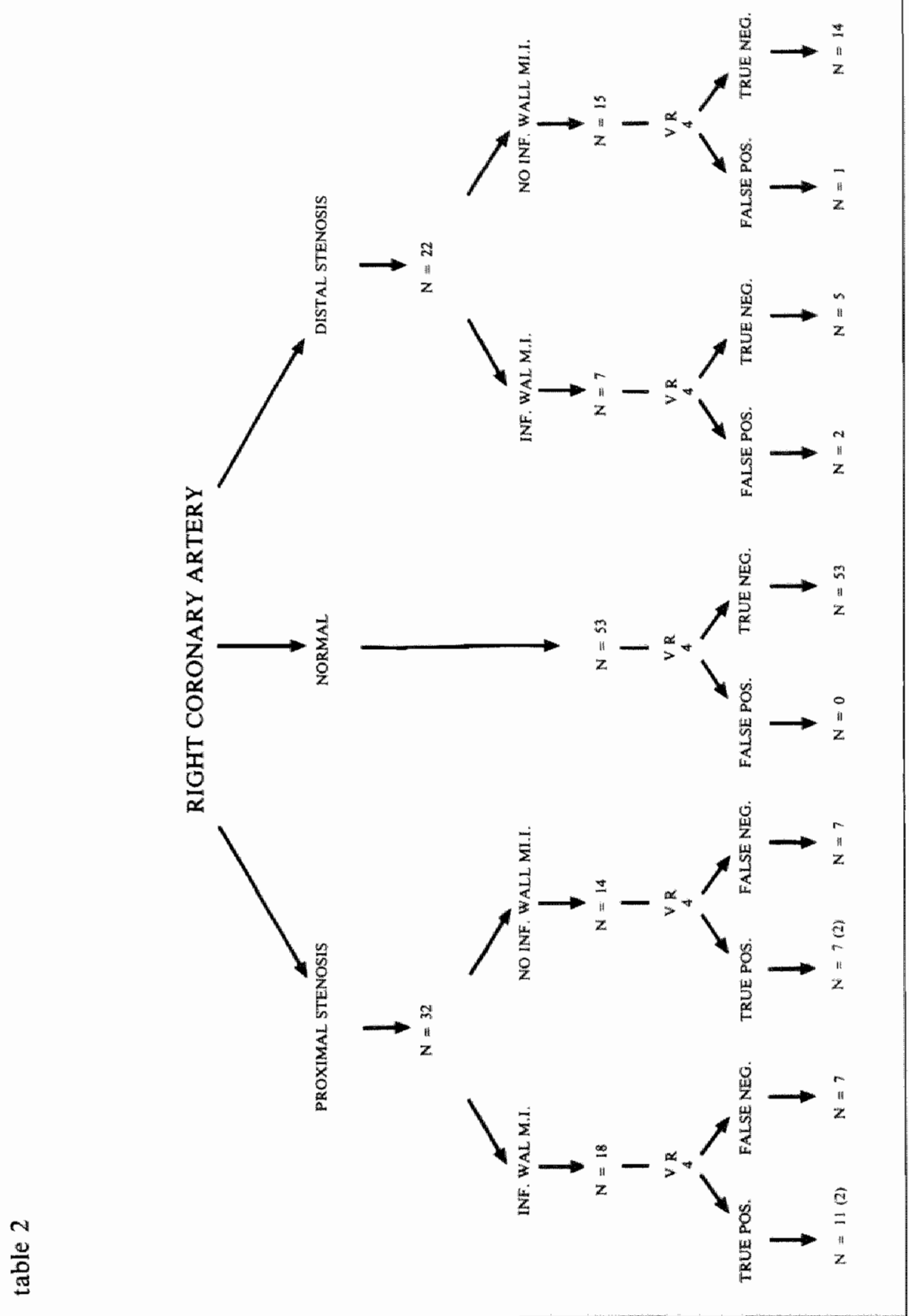




\section{Catheterisation data of the right coronary artery}

Thirty-two patients had at least a narrowing of more than $50 \%$ in the right coronary artery proximal to the first branch to the right ventricle.

Of these patients with a proximal significant stenosis of the right coronary artery 18 patients had suffered from an inferior wall myocardial infarction in the past. Twenty-two patients had a significant stenosis distal to the first branch to the right ventricle, 7 of them had suffered from an inferior wall myocardial infarction in the past. In 3 patients an occlusion in the circumflex artery was judged to be the cause of the inferior wall myocardial infarction. Single vessel disease of the right coronary artery was found in 13 patients. Ten had a significant stenosis proximal to the first branch to the right ventricle. Of these 13 patients $10 \mathrm{had}$ an inferior wall infarction in the past. Three with an occlusion distal to first branch to the right ventricle and 7 with an occlusion proximal to the first branch to the right ventricle.

In 54 patients a significant stenosis was present in the right coronary artery, 32 patients had a proximal stenosis of whom 18 had suffered from an inferior wall myocardial infarction.

In this group of 18 patients with an old inferior wall myocardial infarction caused by an occlusion proximal to the first branch of the right ventricle 11 patients showed $S T$-segment deviation $\geqq 1 \mathrm{~mm}$ in lead $\mathrm{V}_{4} R$. In the 14 patients with a proximal obstruction in the right coronary artery without an inferior wall myocardial infarction 7 times ST-segment deviation $\geqq 1 \mathrm{~mm}$ was noticed in lead $V_{4} R$.

In 22 patients a distal obstruction was present in the right coronary artery, 7 of them had suffered from an old inferior wall myocardial infarction and 2 of them had STsegment elevation $\geqq 1 \mathrm{~mm}$ in lead $V_{4} R$. Only 1 patient in the group of 15 patients without an old inferior myocardial infarction and a significant stenosis distal to the first branch to the right ventricle showed ST-segment elevation in $V_{4} R \geqq 1 \mathrm{~mm}$. None of the 53 patients without a significant stenosis in the right cornary artery showed ST-segment deviation $\geqq 1 \mathrm{~mm}$ in lead $\mathrm{V}_{4} R$.

If we calculate the sensitivity, specificity and predictive accuracy of ST-segment elevation/depression in $V_{4} R$ we come to a sensitivity of $56 \%$, a specificity of $96 \%$ and a predictive accuracy of $84 \%$.

\section{Discussion}

In spite of the fact that the exercise test was performed in a group of patients without discontinuation of anti-anginal treatment and included 21 patients with severe rhythm disturbances results of sensitivity and predictive accuracy of recognition of coronary heart disease using conventional ECG leads are comparable with results of other investigations (13). The specificity of diagnosing ischemic cardiac disease was very high (84\%). Our group of 107 patients consisted of 18 women. Eight of 
them had a true negative exercise test, 4 a false negative exercise test and 6 a true positive exercise test. We have no explanation for the absence of false positive exercise test in our female patients.

To accept a negative exercise test in patients with an old myocardial infarction and single vessel disease as true negative can be a point of discussion. As mentioned in the method section in the conventional ECG leads only ST-segment depression was accepted as suggestive for ischemia. Therefore, ST-segment elevation which may occur in the leads recording from the area of infarction in absence of additional ischemia was excluded. Ideally, to solve this probllem a thallium exercise test would have been of value. An exercise test with a defect which remains unchanged in a patient with an old myocardial infarction and single vessel disease would support the diagnosis of a true negative exercise test. However, no thallium exercise tests were performed in this group of patients.

For the evaluation of the value of $V_{4} R$ to detect ischemia of the right ventricle thallium scintigraphy is of limited value, because the right ventricle is shown in only a low percentage of the redistribution studies.

Until now we do not have a good explanation for the elevation of lead $V_{4} R$ in patients having an acute inferior wall myocardial infarction with a right ventricular infarction. Is the elevation caused by involvement of the posterior part of the septum or by ischemia of the free wall of the right ventricle? It is of importance that none of the patients with a normal right coronary artery had ST-segment deviation in $\mathrm{V}_{4} \mathbb{R}$, also when a significant stenosis in the circumflex coronary artery with or without myocardial infarction was present. This indicates that ST-segment deviation in $\mathrm{V}_{4} \mathrm{R}$ is not caused by reciprocal ST-segment changes from perfusion abnormalities in the posterior wall.

Twenty-one of our patients showed ST deviation $\geqq 1 \mathrm{~mm}$ in lead $V_{4} R$, with only 7 of 14 patients having a significant stenosis in the right coronary artery proximal to the first branch to the right ventricle in the absence of an olld inferior wall myocardial infarction. In the group of 18 patients with an old inferior wall myocardial infarction caused by a proximal occlusion of the right coronary artery 11 patients showed ST-segment deviation. These patients can be considered as being false positive but it is also possible that they are true positive with the right ventricle still having jeopardized myocardium. To solve this problem one might be tempted to determine the ejection fraction of the right ventricle during exercise. In 1979 Berger et al (14), however, showed that the right ventricular function during exercise is not primarily dependent on the presence or absence of a proximal right coronary artery stenosis. Nevertheless, our data show that recording lead $V_{4} R$ during exercise is of help to identify patients with a proximal stenosis in the right coronary artery with or without an old inferior myocardial infarction. 


\section{References}

1. Master AM:

The two-step exercise electrocardiogram: A test for coronary insufficiency. Ann Intern Med $1950 ; 32: 822-863$.

2. Bruce RA, Mornsten TR:

Exercise stress testing in evaluation of patients with ischemic heart disease. Prog Cardiovasc Dis $1969 ; 11: 371-390$.

3. Froelicher VF, Thompson AJ, Longo MB, Trüebwasser JP, Lancaster MC:

Value of exercise testing for screening asymptomatic men for latent coronary artery disease. Prog Cardiovasc Dis 1976; 18: 265-276.

4. Epsteín SF:

Limitations of the electrocardiographic response to exercise in predicting coronary artery disease. New Engl J Med 1975; 293: 367-371.

5. Chaitman BR, Bourassa MG, Wagniart P, Corbara F, Ferguson RR:

Improved efficiency of treadmill exercise testing using a multiple lead ECG system and basic hemodynamic exercise response. Circulation 1978; 57: 71-79.

6. Erhardt LR, Sjögren A, Wahlberg I:

Single right-sided precordial lead in the diagnosis of right ventricular involvement in inferior myocardial infarction. Am Heart J 1976; 91 : $571-576$.

7. Candell-Riera J, Figueras $\mathbf{J}$, Valle $\mathbf{V}$, et al:

Right ventricular infarction: Relationships between ST-segment elevation in $V_{4} R$ and hemodynamic, scintigraphic, and echocardiographic findings in patients with acute inferior myocardial infarction. Am Heart J 1981; 101: 281-287.

8. Braat SH, Brugada P, de Zwaan C, Coenegracht JM, Wellens HJJ:

Value of electrocardiogram in diagnosing right ventricular involvement in patients with an acute inferior wall myocardial infarction. Br Heart $\mathrm{J} 1983 ; 49 ; 368-372$.

9. Croft $\mathbf{C H}_{3}$ Nicod P, Corbett JR, et al:

Detection of acute right ventricular infarction by right precordial electrocardiography. Am J Cardiol $1982 ; 50: 421-427$.

10. Klein HO, Tordjman T, Ninio R, Sareli P, Oren V, Lang R, Gefen J, Pauzner C, Di Segni E, David D, Kaplinsky E:

The early recognition of right ventricular infarction: Diagnostic Accuracy of the Electrocardiographic $V_{4} R$ lead. Circulation 1983; 67: 558-565.

11. Braat SH, Brugada $P$, Den Dulk $K$, van Ommen $V$, Wellens HJJ:

Value of lead $V_{4} R$ for recognition of the infarct coronary artery in acute inferior myocardiall infarction. Am J of Cardiol 1984; 53, 1538-1541. 


\section{Judkins MP:}

Selective coronary arteriography. Radiology $1967 ; 89: 815-824$.

13. Kansal $\mathbf{S}$, Roitman D, Bradley EL, Sheffield $\mathbf{L T}$ :

Enhanced evaluation of treadmill tests by means of scoring based on multivariate analysis and its clinical application: A study of 608 patients. Am J of Cardiol 1983; 52 : 155-1160.

14. Berger HJ, Johnstone DE, Sands JM, Gottschalk A, Zaret BL:

Response of right ventricular ejection fraction to upright bicycle exercise in coronary ar tery disease. Circulation $1979 ; 60: 1292-1299$. 



\section{Chapter 7}

Right ventricular involvement with acute inferior wall myocardial infarction identifies high risk of developing atrio ventricular nodal conduction disturbances

by

Simon H. Braat*, MD, Christoffel de Zwaan*, MD, Pedro Brugada*, MD, Joseph M. Coenegracht**, MD, Hein J.J. Wellens*, MD.

Department of Cardiology* and Nuclear Medicine** University of Limburg, Annadal Hospital Maastricht, The Netherlands

Published in the American Heart Journal 1984, 107: 1183-1186. In part presented at the 31 Annual Scientific Meeting of the American College of Cardiology, Atlanta 1982. 


\section{Summary}

In 67 consecutive patients with acute inferior wall myocardial infarction, $99 \mathrm{~m}$ Technetium pyrophosphate scintigraphy was performed 36 to 72 hours after the onset of chest pain to detect right ventricular inwolvement. All patients were continuously monitored during at least 3 days to detect rhythm and conduction disturbances.

In 29 patients right ventricular invollvement was diagnosed by scintigraphy. None of these 29 patients showed clinical signs of right sided heart failure. Fourteen of the 19 patients showing atrioventricular (AV) nodal conduction disturbances in the setting of an inferior MI also had involvement of the right ventricle (RV). Therefore, the incidence of high degree AV nodal block in patients with $R V$ involvement (14 of 29 patients) was $48 \%$ compared to only $13 \%$ ( 5 of 38) in patients with an inferior MI without RV involvement.

In patients admitted because of acute $\mathrm{MI}_{\text {, }}$ high degree atrioventricular (AV) block has been reported to occur in 12 to $25 \%$ of cases (1-3). It has been shown that the incidence of high degree AV block is 3 times higher in patients with an inferior as compared to patients with an anterior wall infarction (4). This implies that the incidence of high degree AV block in inferior MI is approximately $27 \%$ (18-36\%) (5). The occurrence of AV nodal block is usually explained by the fact that the blood supply to the AV node depends in $90 \%$ of patients on the right coronary artery (RCA) (6). One might therefore, expect a very high incidence of AV nodal block in patients in whom an inferior MI is accompanied by RV involvement because occlusion of the RCA should then be proximal to the branch to the AV node. To study this hypothesis data from 67 consecutive patients, admitted to our coronary care unit, with an inferior MI were retrospectively analysed.

\section{Methods}

Patients.

Sixty-seven consecutive patients with an inferior MI were studied retrospectively. Fifty-six were male and 11 female. Ages ranged from 39 to 80 (mean $57 \pm 9.4$ ) years. Four patients had suffered from a documented myocardial infarction in the past, 2 previously had had an anterior and 2 an inferior wall myocardial infarction. The diagnosis of inferior MI was based on the clinical history, characteristic rise in CPK and SGOT values and appearance of new pathologic $Q$ waves in the inferior leads. 
99mTechnetium pyrophosphate scintigraphy.

In each patient $99 \mathrm{~m}$ Technetium pyrophosphate scintigraphy was performed 36 to 72 hours after the onset of chest pain. Sixty to 90 minutes after the injection of 15-20 mC of $99 \mathrm{mT}$ Technetium pyrophosphate, 3 views were recorded with a general all purpose parallel hole collimator: the anterior, left lateral and $45^{\circ}$ left anterior oblique (LAO). Each view contained at least 600,000 counts.

After the last view, (the $45^{\circ}$ LAO-projection) was recorded, a small bolus of $99 \mathrm{~m}$ Technetium was injected without moving patient or collimator. At the same time a dynamic flow study was performed, using frames of 1 second to visualize separately the $R V$ and the left ventricle. A region of interest was placed where the $R V$ was visualized. By superimposing this area of the $R V$ on the previously obtained $45^{\circ}$ $L A O$ view $R V$ involvement was identified. An Ohio Nuclear Sigma 420 mobile gamma camera with a general all purpose parallel hole collimator interfaced to a MCS-560 mobile computer system and a Philips gamma camera with a general all purpose parallel hole collimator interfaced to a PDS computer system were used for all studies. The radionuclide data were analysed by 2 independent observers without knowledge of the clinical data. The $99 \mathrm{mTechnetium} \mathrm{pyrophosphate} \mathrm{scintigraphy}$ was judged to be positive when there was definite myocardial uptake. RV involvement was considered to be present if definite myocardial uptake was seen in the region of interest of the RV (Fig. 1).

\section{ECG monitoring.}

A 12-lead ECG plus four additional right precordial leads $\left(V_{3} R, V_{4} R, V_{5} R\right.$ and $\left.V_{6} R\right)$ were recorded on admission and routinely every 8 hours during the next three dlays. Leads $V_{3} R, V_{4} R, V_{5} R$ and $V_{6} R$ are the mirror images of lead $V_{3}, V_{4}, V_{5}$ and $V_{6}$ on the right chest wall. At the same time blood samples were drawn to determine CPK and SGOT walues.

All patients had continuous ECG monitoring for at least 3 days to detect rhythm and conduction disturbances. AV block was thought to be located at the AV nodal level when second degree (2:1 or Wenckebach) block developed in the presence of a narrow $\mathrm{QRS}$-complex. Third degree AV block was considered to be located at the AV nodal level when it was associated with an escape rhythm showing a QRScomplex similar to the one recorded during the conducted supraventricular rhythm. No patient had right or left bundle branch block during MI. When conduction disturbances were noted complete ellectrocardiograms including the additional right precordial leads were recorded immediately (Fig. 2).

In none of our patients was invasive hemodynamic monitoring performed, because physical examination revealed no signs of right sided heart dysfunction. 


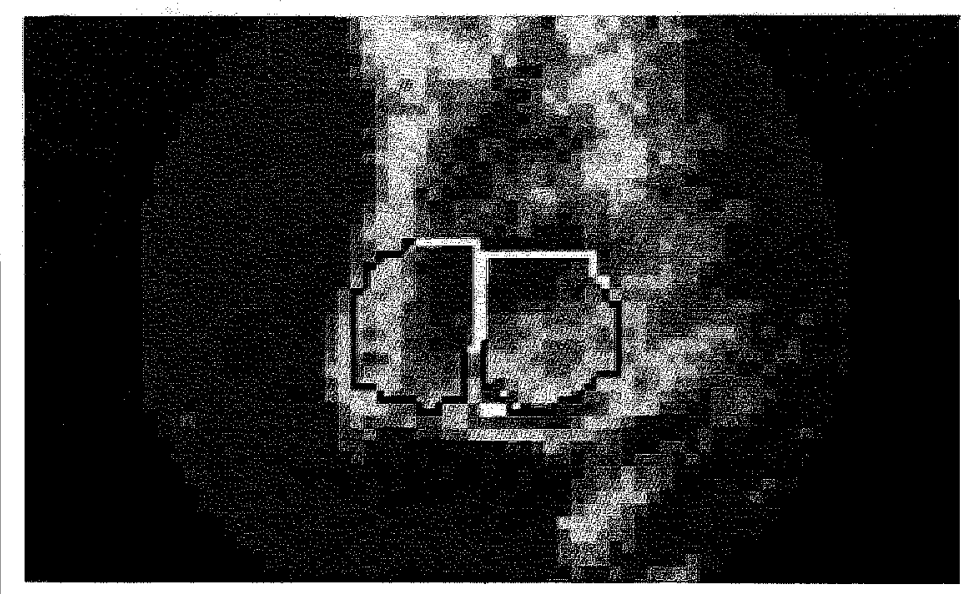

Figure 1 The $45^{\circ}$ left anterior oblique view upon which is superimposed the region of interest drawn around the right and left ventricle. No involvement of the right ventricle is seen.

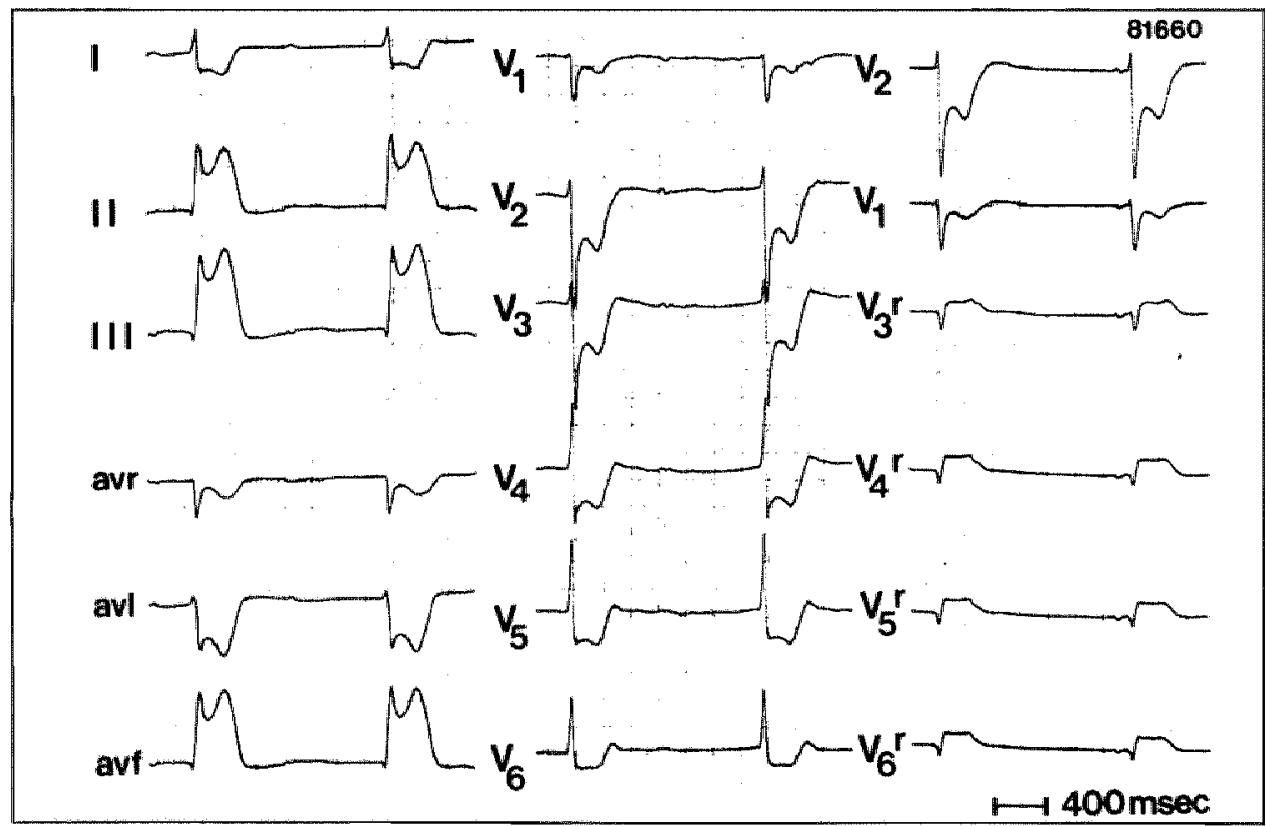

Figure 2 Leads I, II, III, AVR, AVL, AVF, V $, V_{2}, V_{3}, V_{4}, V_{5}, V_{6}$ and leads $V_{2}$, $V_{11}, V_{3} R, V_{4} R, V_{5} R$ and $V_{6} R$ are recorded simultaneously. The electrocardiogram shows an acute infero posterior infarct and a high degree AV nodal block. Note the ST-segment elevation in the right precordial leads indicating right ventricular involvement and the QS-pattern in $V_{4} R$ and $S T$-segment depression in $V_{1}$ and $V_{2}$. 


\section{Results}

\section{Incidence of second and third degree AV block.}

All 67 patients had a positive $99 \mathrm{~m}$ Technetium pyrophosphate scan, indicating the presence of an inferior MI. Twenty-nine $(43 \%)$ of the 67 patients also had involvement of the RV.

Nineteen of the 67 patients had an episode of second or third degree AV block $(28 \%)$. In 5 patients this was already present on admission. In 9 it developed 3 to 24 hours after admission and in 5 within the next 4 days. Therefore in 14 of our patients the conduction disturbances developed within 24 hours after the onset of chest pain. Block did not disappear after an intravenous injection of $0.5 \mathrm{mg}$ of Atropine. High degree AV nodal conduction disturbances were noted during the first 3 days of continuous monitoring in only 5 of the group of 38 patients (13\%) with MI by $\mathbb{E C G}$, but with no RV involvement by pyrophosphate scintigraphy. On the other hand, high degree AV nodal block occurred in 14 out of $29(48 \%)$ of patients with inferior MI by ECG who also had pyrophosphate scintigraphy indicating RV involvement.

In 10 patients a temporary pacemaker was inserted, 8 of them had RV involvement. One patient developed ventricular fibrillation during the introduction of the catheter. This patient had RV involvement on the $99 \mathrm{mTechnetium} \mathrm{scintigraphy.} \mathrm{Only} \mathrm{one}$ of the 67 patients died in hospital. This occurred suddenly on the third day after admission.

At antopsy cardiac rupture was found with severe three vessel disease and a recent inferior wall infarction with RV involvement. This patient had a scintigram positive for RV involvement.

\section{Observations in lead $\mathrm{V}_{4} \mathrm{R}$}

In 29 patients $S T$-segment elevation $\geqq 1 \mathrm{~mm}$ was found in the right precordiall lead $V_{4} R$ (Table 1). In 27 of these patients $R V$ involvement was found on the Technetium pyrophosphate scan. Twelve of the 14 patients with AV conduction disturbances had a scintigram positive for $R V$ infarction and $S T$-segment elevation in $V_{4} R$. "Two patients with ST-segment elevation in lead $V_{4} R$ developed $A V$ conduction disturbances in the absence of RV involvement on the scan.

These data indicate that ST-elevation in lead $V_{4} R$ not only has the same predictive value for the development of high degree AV conduction disturbances (48\%) in patients with an inferior MI, but also is a very sensitive $(0.93)$ and specific $(0.95)$ indicator for RV involvement.

Of interest is the high incidence of AV conduction disturbances in patients with STsegment elevation in $V_{4} R$ and ST-segment depression in $V_{1}$ and $V_{2}$ ( 7 of 9 patients, table 1) and also that the two patients with an old anterior wall infarction develop conduction disturbances. 
Morphology in

$V_{4} R, V_{1}$ and $V_{2}$

ST elevation $V_{4} R$

QS in $V_{4} R$

ST elevation $V_{4} R$

and $Q S$ in $V_{4} R$

ST elevation $V_{4} R$

and $\mathrm{ST}$ depression

in $V_{1}$ and $V_{2}$
In normal $\mathbf{A V}$

conduction

$\mathbf{N}=\mathbf{4 8}$

$15(15)$

$10(8)$

$8(8)$
$9(8)$

In $\mathbf{A V}$ conduction disorders

$\mathrm{N}=19$

14 (12)

$11(8)$

$7(7)$

Abbreviations: $\mathrm{AV}=$ Atrio ventricular nodal. The numbers in parenthesis: Technetium pyrophosphate scan positive for right ventricular involvement.

\section{Discussion}

\section{RCA and AV Node.}

Inferior wall infarction can result either from an occlusion of the RCA, of the circumflex branch from the left coronary artery, or of the left anterior descending coronary artery if it comes over the apex. Blood supply to the AV node is by way of the AV nodal artery. In $90 \%$ of cases this AV nodal artery comes from the RCA. In a varying percentage of cases however, there is a dual blood supply to the AV node, because not only the AV nodal artery but also branches of the first and second septal branches of the left anterior descending artery may bring blood to the AV node $(6,7)$.

\section{AV conduction disturbance with acute inferior $\mathrm{MI}$.}

If one accepts that RV involvement in inferior MI will rarely occur following occlusion of the left coronary artery, but primarily after occlusion of the RCA proximal to the RV branch, which is above the origin of the AV nodal artery, one would expect the incidence of $\mathrm{AV}$ nodal conduction disturbances to be close to $90 \%$ in patients with $\mathrm{RV}$ involvement.

Although the incidence of AV block was higher it was however, not as high as expected. An explanation therefore could be that dual or collateral blood supply to the AV node is functionally common. 
In our group we found a much higher incidence of $\mathrm{AV}$ nodal conduction disturbances in patients with $\mathrm{RV}$ involvement, $48 \%$ as compared to $13 \%$ in patients without $\mathrm{RV}$ involvement.

An alternative for the AV nodal conduction disturbances would be the stimulation of the vagal afferents in the inferior wall of the $\mathrm{RV}$ and left ventricle. In this case one would expect a satisfactory response to atropine and a higher incidence of sinusbradycardia, which was not the case in our group.

In our series (table 1) we found an interesting subgroup of 9 patients in whom $\mathrm{AV}$ nodal conduction disturbances developed in 7. All showed ST-segment elevation in $V_{4} R$ and ST-segment depression in $V_{1}$ and $V_{2}$. One explanation for this could be, that the blood supply by the RCA as well as the left anterior descending to the AV node is impaired. This thesis is supported by the fact that both two patients with an old anterior wall infarction developed AV nodal conduction disturbances in contrast to the two patients with an old inferior wall myocardial infarction.

\section{RV infarction with failure.}

Interest in RV infarction increased after Cohn et al (8) published their observations on the possible hemodynamic consequences of RV infarction and their therapeutic implications. Recently Lloyd et al (9) reported, that in the presence of an inferior MI with hemodynamic signs of RV involvement high degree AV nodal block occurred in $58 \%$ of cases.

\section{VF with cardiac pacing.}

Sclarovsky et al (10) described induction of ventricular fibrillation during introduction of a pacing catheter on cardiac pacing in patients with RV infarction. In our patients VF developed in one of the 10 patients in whom a pacing catheter had to be inserted because of symptomatic bradycardia. It was 1 of the 8 patients with RV involvement. In view of the high incidence of $R V$ infarction in patients developing high degree AV nodal block in the setting of an inferior MI our observations suggest that these patients are not at high risk for developing VF during introduction of a cardiac catheter on cardiac pacing.

\section{Abnormal $\mathrm{V}_{4} \mathrm{R}$.}

Barrillon et al (11), were the first to recognize the value of right precordial leads in identifying a group with high risk of development of high degree AV block. In their observations the presence of a QS pattern and ST elevation in $V_{4} R$ did identify a subgroup of patients with high risk of development of severe AV conduction disturbances. 
It also has previously been reported that $\mathrm{RV}$ involvement can be diagnosed by recording additional. $\mathrm{RV}$ leads $(\mathbb{1 2 - 1 5 )}$. In this study we found that ST-segment elevation in lead $V_{4} R$ has a sensitivity and specificity in predicting $R V$ involvement of 0.93 and 0.95 respectively. We conclude that diagnosing $R V$ infarction by using lead $V_{4} R$ is of value in discovering a subgroup of patients with inferior MI at high risk of developing high degree block in the AV node even in small $R V$ without hemodynamic RV failure.

We thank Frans J. Wackers, MD, Department of Internal and Nuclear Medicine, Hospital of Vermont, Burlington, Vermont, for support and advice during the preparation of this article.

\section{References}

\section{Norris RM, Mercer CJ:}

Significance of idioventricular rhythms in acute myocardial infarction. Progr Cardiovase Dis 16:455, 1974.

\section{Resnekov L, Lipp H:}

Pacemaking and acute myocardial infarction. Progr Cardiovasc Dis 14:475. 1972.

\section{Rotman M, Wagner GS, Wallace AG:}

Bradyarrhythmias in acute myocardial infarction. Circulation 45:703, 1972.

4. Bigger JT, Dresdale RJ, Heissenbuttel RH, Weld FM, Wit AL:

Ventricular arrhythmias in ischemic heart disease: Mechanism prevalence, significance and management. Progr Cardiovasc Dis 19:255, 1976.

5. Tans AC, Lie KI, Durrer D:

Clinical setting and prognostic significance of high degree atrioventricular block in acute inferior nuyocardial infarction: A study of 144 patients. Am Heart J 99:4, 1980.

\section{James TN:}

The coronary circulation and conduction system in acute myocardial infarction. Progr Cardiovase Dis 10:410, 1968.

\section{Becker AE, Anderson RH:}

The morphology of the human atrio ventricular junctional area. In The Conduction System of the Heart, Wellens HJJ, Lie KI, Janse MJ, Stenfert Kroese, Leiden, p. $263,1976$.

8. Cohn JN, Guiha NH, Broder MI, Limas CJ:

Right ventricular infarction: Clinical and hemodynamic features. Am J Cardiol 33:209, 1974 . 
9. Lloyd EA, Gersh BI and Kennelly BM:

Hemodynamic spectrum of "dominant" right ventricular infarction in 19 patients. Am $J$ of Cardiol $48: 1016,1981$.

10. Sclarovsky S, Zafrir N, Strasberg B, Kracoff O, Lewin RF, Ardïti A, Rosen KM, Agmon J:

Ventricular fibrillation complicating temporary ventricular pacing in acute myocardial infarction: Significance of right ventricular infarction. Am J of Cardiol 48:1160, 1981 .

11. Barrillon $\mathbf{A}$, Chaignon $\mathbf{M}$, Guize $\mathbf{L}$, Gerbaux $\mathbf{A}$ :

Premomitory sign of heart block in acute posterior myoacardial infarction; Br Heart J $37: 2,1975$.

12. Braat SH, Brugada P, Coenegracht JM, Bär FW, Wellens HJJ:

The value of right precordial leads in detection of right ventricular infarction. A comparison with $99 \mathrm{mTc}$ pyrophosphate scintigraphy. Circulation 64, IV-86, 1981, Abstract.

13. Erhardt LR, Sjogren A, Wahlberg I:

Single right sided precordial lead in the diagnosis of right ventricular involvenent in ünferior myocardial infarction. Am Heart I 91,571, 1976.

14. Candell Riera J, Figueras J, Valle V, Alvarez A, Gutierrez L, Cortadellas J, Cinca J, Salas A, Rius $\mathbf{J}$ :

Right ventricular infarction: Relationships between ST segment elewation in $\mathrm{V}_{4} \mathrm{R}$ and hemodynamic, scintigraphic and echocardiographic findings in patients with acute inferior myocardial infarction. Am Heart J 101:281, 1981.

15. Braat SH, Brugada P, de Zwaan C, Coenegracht J, Wellens HJJ:

Value of electrocardiogram in diagnosing right ventricular involwement in patients with an acute inferior wall myocardiol infarction. Br Heart $J 49,368-372,1983$. 



\section{Chapter 8}

\section{Right and left ventricular ejection fraction in acute inferior wall infarction with or without ST-segment elevation in $\mathrm{V}_{4} \mathrm{R}$}

by

Simon H. Braat, MD, Pedro Brugada, MD, Chris de Zwaan, MD, Karel den Dulk, MD, Hein J.J. Wellens, MD, FACC. Department of Cardiology, University of Limburg, Annadal Hospital, Maastricht, The Netherlands

Presented in part at the 31th Annual Meeting of the Society of Nuclear Medicine in Los Angeles, 1984

Accepted for publication in the Journal of the American College of Cardiology 


\section{Summary}

To detect right ventricular involvement lead $V_{4} R$ was recorded within 10 hours of onset of chest pain in 42 consecutive patients admitted with an inferior wall myocardial infarction (MI). One week after the acute MI multigated equilibrium radionuclide ventriculography was performed to assess right (RV) and left ventricular (LV) ejection fraction (EF). Two weeks after the acute MI coronary angiography was performed to determine the site and location of the obstruction, leading to the acute MI. Seventeen patients had an obstruction in the right coronary artery (RCA) proximal to the first branch to the $R V$ free wall (group I). All had shown ST-segment elevation in lead $V_{4} R$. Fourteen patients had an obstruction in the RCA distal to the first branch to the RV free wall (group II). Only 2 of these patients had ST-segment elevation in lead $V_{4} R$. In 11 patients the obstruction was located in the circumflex coronary artery (group III). None of these patients had ST-segment elevation in lead $V_{4} R$. Nineteen patients had $S T$-segment elevation $\geqq 1 \mathrm{~mm}$ in lead $V_{4} R$ (group IV). LVEF was not different in these groups of patients, while the $\mathbb{R V E F}$ was significantly lower in the group of patients with a proximal obstruction in the RCA and in the group of patients previously having ST-segment elevation $\geq 1 \mathrm{~mm}$ in lead $\mathrm{V}_{4} \mathrm{R}$.

Conclusion: $S T$-segment elevation in lead $V_{4} R$ reliably identifies the group of patients with depressed right ventricular function. This persists for at least one week.

Acute inferior wall myocardial infarction (IWMI) can be the result of occlusion of the right coronary artery (RCA), circumflex coronary artery (CA) or a long left anterior descending coronary artery (LAD) extending over the apex of the left ventricle to the inferior wall. Occlusion of such a long LAD may lead to an electrocardiographic pattern of both anterior and IWMI. The differentiation between occlusion of the RCA or CA cannot be made on the standard 12-lead electrocardiogram (ECG). It can, howver, be done when additional right precordial leads and particularly lead $V_{4} R$ are recorded (1). It has been shown (2-5) that recording the right precordial lead $V_{4} R$ in patients with acute IWMI allows for recognition of involvement of the right ventricle (RV) in addition to left ventricular (LV) infarction. Two groups of patients can be differentiated by recording lead $V_{4} R$ during the acute phase of IWMI:

a. Those showing ST-segment elevation in lead $V_{4} R \geq 1 \mathrm{~mm}$. In these patients a proximal occlusion of the RCA before the take off of the first RV branch is extremely likely (1).

b. patients without ST-segment elevation in lead $\mathrm{V}_{4} \mathrm{R}$. In these patients IWMI can be the result of either a distal occlusion of the RCA, or an occlusion of the CA. Following acute MI the value of left ventricular ejection fraction (LVEF) has important prognostic significance $(6,7)$. It is conceivable that the degree of impairment of right and left ventricular function in acute myocardial infarction is related to the site and level of the stenosis in the coronary artery (RCA or CA) responsible for infarction. 
In this study we therefore prospectively evaluated RV and LV function in patients with IWMI in relation to the vessel responsible for the infarction. In addition the predictive value of ST-segment elevation in right chest lead $V_{4} R$ to diagnose right ventricular dysfunction was analysed.

\section{Patients and methods}

Forty-two consecutive patients were included in this study. Ages ranged from 33 to 69 (mean 54) years. All patients fulfilled the following criteria:

1. typical history of chest pain, lasting more than 30 minutes,

2. admission within 10 hours of chest pain,

3. characteristic cardiac enzyme pattern of serum glutamic oxaloacetic transaminase and creatine phosphokinase for acute myocardial infarction

4. characteristic electrocardiographic changes for acute inferior wall myocardial infarction: serial ST-T-wave changes and the development of Q-waves in lead II, III and AVF.

On admission and every 8 hours during the next 3 days a standard 12 -lead ECG and an additional right chest wall lead $\mathrm{V}_{4} \mathrm{R}$ were recorded. At the time of the ECGrecordings blood was taken to determine the serum levels of creatinephosphokinase and SGOT.

Approximately 7 days after onset of acute $\mathrm{MI}_{\text {, }}$ multigated equilibrium cardiac blood pool imaging was performed using in-vivo labeling of autologous red blood cells with $15 \mathrm{mCi}$ of $99 \mathrm{mTechnetium} \mathrm{(8).}$

Images were acquired using a Philips gamma camera with a parallel-hole-all purpose collimator, interfaced to a dedicated Philips minicomputer. Data acquisition was performed in that left anterior oblique position in which the best separation between the right and left ventricles was achieved. Left and right ventricular ejection fractions (LVEF) were calculated using a semi-automatic commercial available soft ware program, which has previous been validated by Standke et al (9).

The normal value for LVEF in our laboratory is $\geq 60 \%$ and for the RVEF $\geq 40 \%$. Ten to 14 days (mean 12.5) after the MI a cardiac catheterisation was performed including a left ventriculography and right and left coronary artery angiography. A reduction of $\geqq 50 \%$ in the luminal diameter of a coronary artery was considered significant. The coronary angiograms were judged by two cardiologists. Differences in opinion were resolved by consensus.

The coronary artery demonstrating a complete obstruction or subtotal luminal narrowing was assumed to be the "infarct vessel". In the RCA the location of a stenosis was recorded relative to the take off of the first branch to the right ventricular free wall. No attention was paid to the conus branch. 


\section{Results (Table 1)}

\section{Angiographic data}

In 31 patients the RCA was the "infarct vessel" , in 17 the occlusion was proximall (group 1), in 14 distal (group II) to the first branch to the free wall of the right ventricle. In 11 patients the infarct vessel was the CA (group 3).

\section{Electrocardiographic findings on admission and "infarct vessel"}

Nineteen out of 42 patients ( $45 \%$ ) showed ST-segment elevation $\geqq 1 \mathrm{~mm}$ in lead $\mathrm{V}_{4} \mathrm{R}$ (group 4). All 19 patients had occlusion of the RCA. In 17 patients ( $89 \%$ ) the occlusion was located proximal to the first RV branch, while in the 2 other patients the stenosis was located in the RCA distal to the first RV branch, but proximal to a second RV branch. Twenty-three patients had no ST-segment elevation. In 12 patients the stenosis was located in the RCA. In none of these patients the occlusion was located proximal to the first RV branch. None of the 11 patients with an occlusion in the CA, had ST-segment elevation in $V_{4} R$. In none of the 42 patients STsegment elevation was seen in the precordial leads $V_{1}$ to $V_{5}$.

\section{Table 1}

Left and right ventricular ejection fraction. Number of vessels showing significant stenosis and the location of the lesion causing IWMI

\begin{tabular}{|c|c|c|c|c|}
\hline No & LVEF & RVEF & $\begin{array}{l}\text { No. of Cor.A with } \\
\text { stenosis } \geq \mathbf{5 0 \%}\end{array}$ & $\begin{array}{l}\text { Location of the stenosis } \\
\text { or occlusion which caused } \\
\text { the MII }\end{array}$ \\
\hline 1. & 64 & 27 & 1 & prox. RCA \\
\hline 2. & 52 & 48 & 1 & distal RCA \\
\hline 3. & 66 & 35 & 1 & prox. RCA \\
\hline 4. & 45 & 43 & 3 & $\mathrm{CA}$ \\
\hline 5. & 48 & 43 & 3 & $\mathrm{CA}$ \\
\hline 6. & 66 & 44 & 2 & distal RCA \\
\hline 7. & 59 & 47 & 2 & distal RCA \\
\hline 8. & 50 & 19 & 3 & prox. RCA \\
\hline 9. & 60 & 40 & 2 & $\mathrm{CA}$ \\
\hline 10. & 43 & 44 & 3 & distal RCA \\
\hline 11. & 49 & 28 & 2 & prox. RCA \\
\hline 12 & 51 & 30 & $\Perp$ & prox. RCA \\
\hline 13 & 57 & 46 & 1 & distal RCA \\
\hline 14. & 46 & 45 & 1 & $\mathrm{CA}$ \\
\hline
\end{tabular}




\begin{tabular}{|c|c|c|c|c|}
\hline 15 & 42 & 1 & $\mathrm{CA}$ & - \\
\hline 16. & 42 & 3 & distal RCA & - \\
\hline 17. & 40 & 2 & $\mathrm{CA}$ & - \\
\hline 18. & 40 & 2 & distal RCA & - \\
\hline 19. & 44 & 1 & $\mathrm{CA}$ & - \\
\hline 20 & 44 & $\mathbb{1}$ & distal RCA & - \\
\hline 21 & 43 & 3 & $\mathrm{CA}$ & - \\
\hline 22. & 33 & 2 & prox. RCA & + \\
\hline 23 . & 42 & 3 & prox. RCA & + \\
\hline 24. & 47 & 3 & $\mathrm{CA}$ & - \\
\hline 25. & 30 & 1 & prox. RCA & + \\
\hline 26. & 33 & 2 & prox. RCA & + \\
\hline 27. & 42 & 3 & distal RCA & - \\
\hline 28. & 44 & 3 & distal RCA & - \\
\hline 29. & 31 & 3 & distal RCA & + \\
\hline 30. & 23 & $\mathbb{1}$ & prox. RCA & + \\
\hline 31 . & 23 & 2 & prox. RCA & + \\
\hline 32. & 44 & 3 & $\mathrm{CA}$ & - \\
\hline 33. & 46 & 3 & distal $\mathbb{R C A}$ & - \\
\hline 34. & 16 & 1 & prox. RCA & + \\
\hline 35. & 14 & 2 & prox. RCA & + \\
\hline 36. & 37 & 2 & distal RCA & + \\
\hline 37. & 50 & 2 & CA & - \\
\hline 38. & 26 & 2 & prox. RCA & + \\
\hline 39. & 48 & 1 & prox. RCA & + \\
\hline 40. & 48 & 3 & distal RCA & - \\
\hline 41. & 31 & 3 & prox. RCA & + \\
\hline 42. & 27 & 1 & prox. RCA & + \\
\hline
\end{tabular}

$\vec{X}$ LVEF $=53.3 \pm 10$

$\overline{\mathrm{X}} \mathrm{RVEF}=37.4 \pm 10$

Abbreviations:

LVEF = left ventricular ejection fraction; RVEF = right venricular ejection fraction; prox $=$ proximal to the first branch to the right ventricle; $\mathrm{RCA}=$ right coronary artery; $\mathrm{CA}=$ circumflex coronary artery; IWMI = inferior wall myocardial infarction. Cor. $\mathrm{A}=$ Coronary Arteries. 
LVEF and RVEF and "infarct vessel" (Table 2)

LVEF ranged from 36 to $70 \%$ (mean $53 \% \pm 10$ ) and RVEF ranged from 14 to $50 \%$ (mean $37 \% \pm 10$ ) for the whole group of patients. In 17 patients with a proximal RCA occlusion (group 1), mean LVEF was $55 \pm 7 \%$ (mean + s.d.). Mean RVEF value was $29 \pm 9 \%$.

In 14 patients with a distal RCA occlusion mean LVEF (group 2) was $56 \pm 7 \%$ and mean RVEF was $43 \pm 5 \%$.

In 11 patients with an occlusion in the CA (group 3) mean LVEF was $53 \pm 9 \%$ and RVEF was $44 \pm 3 \%$.

There was no statistically significant difference in mean LVEF between the 3 groups. Mean RVEF was significantly lower in patients of group 1, compared to group 2 and 3 ( $\mathrm{p} \leqq 0.001)$ according to the unpaired Student $\mathbb{T}$-test.

\section{LVEF and RVEF and electrocardiographic findings}

Of 19 patients with ST-segment elevation in $V_{4} R$ during the acute phase of myocarclial infarction 17 had abnormal RVEF seven days later. Mean RVEF in this group was $29 \% \pm 8$. All 23 patients without ST-segment elevation in $V_{4} R$ had normal RVEF: Mean RVEF in this group was $44 \% \pm 3(\mathrm{p} \leqq 0.001)$. Of 19 patients with ST-segment elevation in $V_{4} R 14$ patients had a depressed LVEF. Mean LVEF in this group was $54 \% \pm 7$. Fourteen out of 23 patients without ST-segment elevation in lead $V_{4} R$ had an abnormal LVEF $(p=N S)$. The mean LVEF in this group was $56 \% \pm 7$.

One patient (no. 31) died. On admission this patient had a total atrio-ventricular block and he only showed signs of right sided heart failure. The central venous pressure was elevated. The blood pressure was $70 / 40 \mathrm{mmHg}$. With a Swan-Ganz catheter the pressures in the right side were measured. The end diastolic pressure in the right ventricle was twice as high as the wedge pressure. After a fluid load and insertion of a temporary pacemaker the hemodynamic situation improved rapidly. Three weeks after the acute MI the patient died suddenly. Post mortem examination revealed severe three vessel disease and signs of an IWMI with an enormously dilated right ventricle (Fig. 1). However, there were no signs of a reinfarction, suggesting that he suffered from a fatal arrhythmia. 


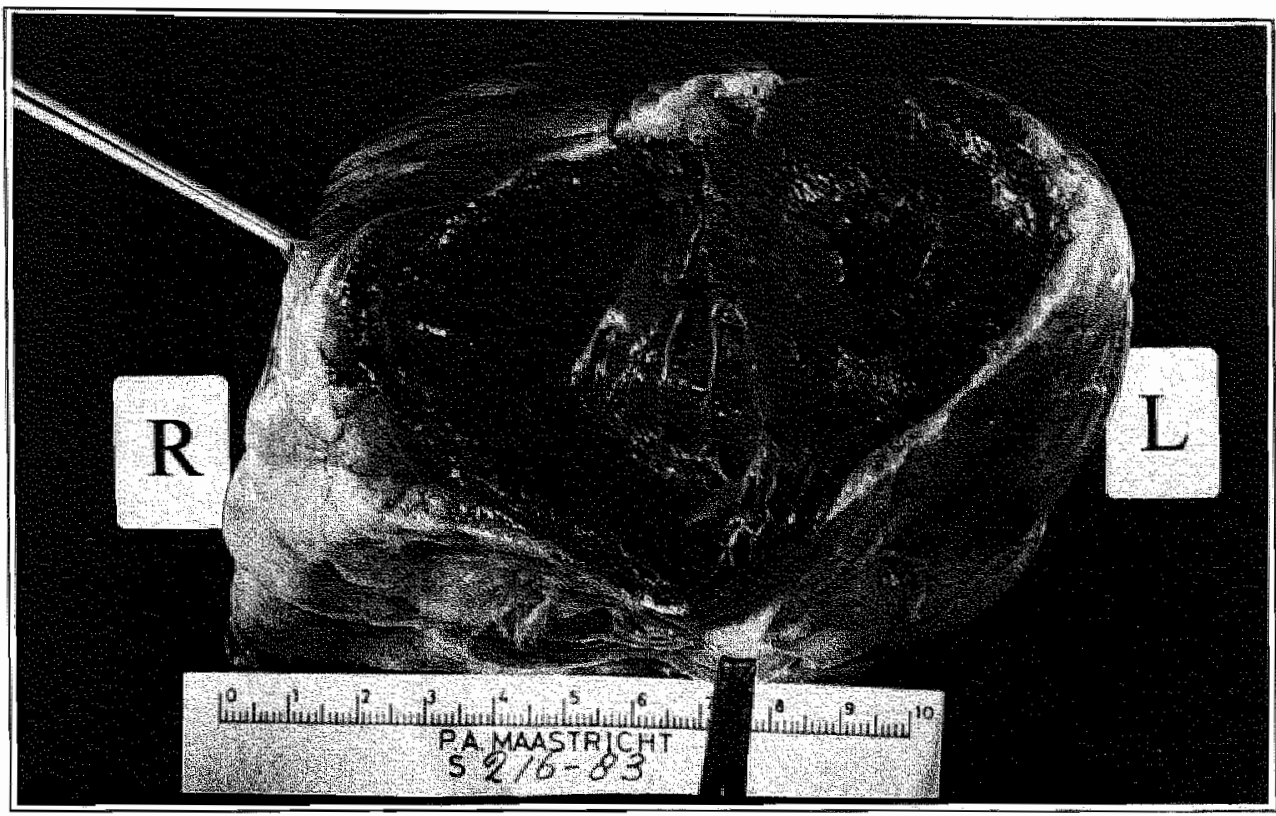

Figure 1 The heart of the only patient who died three weeks after the acute MI. As you can see the RV is markedly dilated while the left ventricle looks normal.

\section{Table 2}

LVEF and RVEF in the different groups of patients studied

\section{LVEF}

RVEF

Occlusion proximal to the first branch to the right ventricle in the $\mathrm{RCA}(\mathrm{N}=17)$

Occlusion distal to the first branch to the right ventricle in the RCA $(\mathrm{N}=14)$

Occlusion in the circumflex coronary artery

$(\mathrm{N}=11)$

$53 \pm 9 \%$

ST-segment elevation $\geqq 1 \mathrm{~mm}$ in $V_{4} R$

$(\mathrm{N}=19)$

$54 \pm 7 \%$

$29 \pm 8 \%$

No ST-segment elevation in lead $V_{4} R$

$\left(N^{\prime \prime}=23\right)$

$56 \pm 7 \%$

$44 \pm 3 \%$

Abbreviations: See table 1. 


\section{Discussion}

The present study demonstrates that ST-segment elevation in $\mathrm{V}_{4} \mathrm{R}$ observed during the acute phase of inferior wall myocardial infarction is indicative of depressed global right ventricular function. The findings also confirm our previous observation that as a rule patients with ST-segment elevation in $\mathrm{V}_{4} \mathrm{R}$ have a proximal stenosis of the RCA. Therefore, a simple and inexpensive tool, such as the electrocardiogram, provides information that may be critical for appropriate clinical management of patients with inferior wall MI. Our data do not support the data of Geft et al (8) while in none of the 42 patients ST-segment elevation in the precordial leads was observed. In the present study only 1 of 17 patients with a depressed RVEF has clinical signs of right sided heart failure. Thus the right ventricular dysfunction often is clinically not noticed and appears to have no short term prognostic significance. In the whole study population the LVEF was well preserved (mean LVEF $53 \% \pm 10$ ). In the 17 patients with a depressed RVEF, 14 also had depressed LVEF, while in the 25 patients with a normal RVEF 14 patiens had a depressed LVEF. The calculation of the right ventricular ejection fraction in a multigated study is complicated by the changing overlap of the right atrium. Because there are no reasons to believe that there is a difference between the overlap of the right atrium in these groups we believe that we are justified in comparing the value of RVEF derived by multigated nuclear techniques in these groups.

Whether or not changes in RV-function after IWMI have indeed independent long term prognostic significance, can only be answered by a long follow up study of these patients. Also in regard to follow up other questions remain presently unanswered, such as in what percentage of RVI develops right sided failure? How extensive must RVI be in these patients?

Our study does not make clear what amount of damage to the RV is required to result in the clinical picture of RVI. Although the incidence of this picture is small, early recognition and appropriate treatment is important because treatment of cardiogenic shock in this setting is very different from patients having shock from massive involvement of the LV (10).

When RV involvement during IWMI does not result in hemodynamic problems one is inclined to believe that a minor part of the posterior septum and inferior wall of the RV led to the ECG-changes in the right precordial leads. Because of the uncomplicated course of these patients one might also believe that no or very minimal abnormalities in RV function are present. Our study shows that occlusion of the RCA in patients before the RV branch severe depression of the RVEF is present. While none of these patients (except for patient 31 ) had clinical signs of right-sided heart failure. However, in our department hemodynamic monitoring is only performed when a patient is in a bad hemodynamic condition. So hemodynamic abnormalities could have been present in those patients with right ventricular infarction. Our find- 
ings indicate that in all patients with $S T$ elevation in $V_{4} R$ permanent damage to the RV had been produced during acute $\mathrm{MI}$.

\section{Acknowledgement}

We express our appreciation to Serve Halders, Irene Cajot and Gerda Saat for their technical and to Miep Schrooders for her secretarial assistance.

\section{References}

1. Braat SH, Brugada P, den Dulk K, van Ommen V, Wellens HJJ:

Value of lead $V_{4} R$ for recognition of the infarct vessel in patients with an acute inferior myocardial infarction. Am J of Cardiol 1984, 53: 1538-1541.

2. Braat SH, Brugada P, de Zwaan C, Coenegracht JM, Wellens HJJ:

Value of the electrocardiogram in diagnosing right ventricular involvement in patients with an acute inferior wall myocardial infarction. Br Heart J 1983, 49: 368-72.

3. Erhardt LE, Sjögren A, Wahlberg I:

Single right-sided precordial lead in the diagnosis of right ventricular involvement in inferior myocardial infarction. Am Heart J 1976; 91: 571-76.

4. Candel-Riera J, Figueras J, Valle V, Alvarez A, Gutierrez L, Cortadellas J, Cinca J, Salas A, Rius J:

Right ventricular infarction: Relationships between ST-segment elevation in $V_{4} R$ and hemodynamic, scintigraphic, and echocardiographic findings in patients with acute inferior myocardial infarction. Am Heart J 1981; 101: 281-87.

5. Croft CH, Nicod P, Corbett JR, Lewis SEm Huxley R, Mukharji J, Willerson JT, Rude RE:

Detection of acute right ventricular infarction by right precordial electrocardiography. Am J Cardiol 1982; 50: 421-27.

6. The Multicenter Postinfaretion Research Group:

Risk stratification and survival after myocardial infarction. New Engl J of Med 1983, 309: 331-36.

7. Schulze RAJ, Strauss HW, Pitt B:

Sudden death in the year following myocardial infarction relation to ventricular premature contractions in the late hospital phase and left ventricular ejection fraction. Am J Med 1977, 62: 192-99.

8. Pavel DG, Zimmer AM, Patterson VN:

In vivo labeling of red blood cells with $99 \mathrm{mTc}$. A new approach to blood pool visualization. INucl Med 1977, 18: 305-308. 
9. Standke $\mathbf{R}$, Hör $\mathbf{G}$, Maul FD:

Fully automated sectorial equilibrium radionuclide ventriculography: Proposal of a method for routine use: Exercise and follow up. Eur J Nucl Med 1983, Vol. 8; 77-83.

10. Cohn JN, Guiha NH, Broder MI, Limas CJ:

Right ventricular infarction clinical and hemodynamic features. Am J Cardiol 1974, 33: 209-214. 


\section{Chapter 9}

\section{Conclusions}

This thesis reports on the value of lead $V_{4} R$ to obtain information about right ventricular involvement and possible complications in the setting of severe ischemia or infarction of the inferior wall of the myocardium. The following conclusions can be drawn:

1. Using technetium $99 \mathrm{~m}$ pyrophosphate imaging to diagnose right ventricular involvement, in patients with acute inferior myocardial infarction the sensitivity, specificity and predictive accuracy of lead $V_{4} R$ to detect right ventricular involvement was found to be $93 \%, 95 \%$ and $93 \%$ respectively.

2. All patients with a subtotal or total stenosis in the right coronary artery proximal to the first branch to the right ventricle showed ST-segment elevation $\geq 1 \mathrm{~mm}$ in lead $V_{4} R$. No ST-segment elevation in lead $V_{4} R \geqq 1 \mathrm{~mm}$ was seen, however, in patients with an acute inferior wall myocardial infarction caused by an occlusion of the left circumflex coronary artery.

3. As shown in a case report the observations described under 2 can have important implications when emergency procedures are necessary in the patient with an acute inferior wall myocardial infarction.

4. ST-segment deviation $\geqq 1 \mathrm{~mm}$ in lead $\mathrm{V}_{4} \mathrm{R}$ during exercise testing strongly suggests a critical stenosis in the proximal part of the right coronary artery. In patients without an inferior wall infarction this finding has a sensitivity of $50 \%$.

5. ST-segment elevation in $\mathrm{V}_{4} \mathrm{R} \geq 1 \mathrm{~mm}$ in the setting of an acute inferior wall myocardial infarction is of great importance to recognize patients at risk for developing high degree AV-block. Approximately $50 \%$ of patients with an acute inferior wall myocardial infarction and ST-segment elevation $\geq 1 \mathrm{~mm}$ developed atrio-ventricular-nodal conduction disturbances, while this was only seen in 13\% of patients with an acute inferior wall myocardial infarction without ST-segment elevation $\geq 1 \mathrm{~mm}$ in lead $V_{4} R$.

6. Patients with inferior wall infarction showing $S T$-segment elevation in $V_{4} R$ during the acute phase have significantly lower right ventricular ejection fractions than patients without this finding. In summary, the finding of ST-segment elevation $\geq 1 \mathrm{~mm}$ in lead $\mathrm{V}_{4} \mathrm{R}$ in the setting of an acute inferior wall myocardial infarction is of value, because it provides information on the site of obstruction, prevalence of subsequent $A V$ nodal block, and right ventricular dysfunction. Therefore, lead $V_{4} R$ should be recorded in every patient with an acute inferior wall myocardial infarction. The registration of lead $V_{4} R$ during exercise testing is useful to recognize a critical stenosis in the right coronary artery. 


\section{Summary}

Following the introduction, the methods section describes the experimental techniques used in this study. The placement of the right chest wall leads, the normal electrocardiographic pattern in these leads and, the measurement of ST-segment deviation are discussed. Two radionuclide techniques are described:

1. Pyrophosphate imaging. The principles, procedures and limitations of this technique for the detection of right ventricular infarction are discussed together with the use of bolus radionuclide injection to localize the right ventricular wall.

2. Multigated cardiac blood pool imaging. The imaging techniques, data processing methods and means of calculating right and left ventricular ejection fractions are described. The validation and limitation of this technique are also discussed. The methodology section also describes the determination of LVEF and coronary artery stenosis by contrast angiography. In chapter 3 the value of the electrocardiogram in diagnosing right ventricular involvement in patients with an acute inferior wall myocardial infarction is described. We found that ST-segment elevation $\geq 1$ $\mathrm{mm}$ in lead $\mathrm{V}_{4} R$ was a sensitive and specific sign for right ventricular involvement when 'compared with technetium pyrophosphate imaging as the "gold standard". Chapter 4 describes the value of lead $V_{4} R$ recording for recognition of the occluded vessel in patients with acute inferior wall myocardial infarction.

The absence of ST-segment elevation excludes proximal occlusion of the right coronary artery while ST-segment elevation $\geqq 1 \mathrm{~mm}$ in lead $V_{4} R$ has a $100 \%$ sensitivity to predict proximal occlusion in this vessel. Chapter 5 is a case report emphasizing the clinical value of detecting ST-segment elevation $\geqq 1 \mathrm{~mm}$ in lead $\mathrm{V}_{4} \mathrm{R}$ in a patient with previous bypass surgery. The recognition of right coronary graft occlusion enabled immediate and successful streptokinase therapy.

In chapter 6 the value of recording lead $V_{4} R$ during exercise testing in predicting proximal stenosis in the right coronary artery is described. The specificity of STsegment elevation $\geqq 1 \mathrm{~mm}$ in lead $\mathrm{V}_{4} \mathrm{R}$ in predicting or excluding proximal stenosis in the right coronary artery is very high at $95 \%$. The sensitivity is $56 \%$ giving an overall predictive value of $84 \%$.

Chapter 7 describes the clinical significance of ST-segment elevation $\geqq 1 \mathrm{~mm}$ in $V_{4} R$ during the acute stage of inferior wall myocardial infarction. The prevalence of subsequent atrioventricular nodal conduction disturbances is significantly higher in patients with this indicator of proximal right coronary occlusion.

Chapter 8 describes a study of the right and left ventricular ejection fraction in patients with acute inferior myocardial infarction. In those with ST-segment elevation $\geq 1 \mathrm{~mm}$ in $\mathrm{V}_{4} \mathrm{R}$ the $\mathrm{RVEF}$ was significantly lower than in the group without the electrocardiographic abnormality. There were no differences in mean LVEF between the two groups. 


\section{Samenvatting}

$\mathrm{Na}$ een introductie worden de methoden, die gebruikt worden, beschreven. Allereerst wordt aangegeven hoe de plaatsing van de rechts precordiale afleidingen is. Hoe het normale patroon van deze afleidingen is en de manier waarop ST-segment elevaties worden gemeten. Verwolgens worden de radionucleaire technieken beschreven. Eerst hoe met behulp van Technetium pyrofosfaat de localisatie van het hartinfarct plaats vindt en vervolgens hoe met behulp van een bolustechniek vastgesteld wordt of de rechter ventrikel ook in het infarctgebied is betrokken. Ook wordt aandacht geschonken aan de beperkingen van deze techniek. Daarna wordt de multigated cardiac blood pool imaging beschreven, met name de opnametechniek, de bewerkingsmethode en de wijze waarop de berekening van de linker en rechter ventrikel ejectiefractie plaats vindt. Ook bij deze techniek worden de beperkingen beschreven. Voorts vindt er een validatie van deze techniek plaats. Het laatste deel van de methodologie betreft de angiografische technieken; hoe de linker ventrikel ejectiefractie berekend wordt met behulp van een angiogram, en de wijze waarop coronair angiogrammen beoordeeld worden.

In hoofdstuk 3 wordt de waarde van het electrocardiogram om rechter ventrikelinfarcering vast te stellen bij patienten met een acuut onderwandinfarct beschreven. Vastgesteld werd dat $S T$-segment $\geqq 1 \mathrm{~mm}$ in afleiding $V_{4} R$ een zeer gevoelig en specifiek teken is voor rechter kamerinfarcering.

Hoofdstuk 4 beschrijft de waarde van afleiding $V_{4} R$ voor het herkennen van die kransslagader, die verantwoordelijk is geweest voor het acute onderwandinfarct. De afwezigheid van ST-segment elevatie in afleiding $V_{4} R$ sluit een proximalle afsluiting van de rechter coronair arterie uit, terwijl ST-segment elevatie $\geqq 1 \mathrm{~mm}$ in afleiding $\mathrm{V}_{4} \mathrm{R}$ een gevoeligheid van $100 \%$ heeft om een proximale stenose in de rechter coronair arterie te voorspellen.

Hoofdstuk 5 is een ziektegeschiedenis, waarbij de waarde van ST-segment elevatie $\geq 1 \mathrm{~mm}$ in afleiding $\mathrm{V}_{4} \mathrm{R}$ bij een patient na bypasschirurgie wordt beschreven. $\mathrm{Nu}$ waren we in staat onmiddellijk de afgesloten bypass te injecteren met streptokinase. In hoofdstuk 6 wordt de waarde van afleiding $V_{4} R$ bij inspanning beschreven om een proximale afsluiting in de rechter coronair arterie vast te stellen. De specificiteit van ST-segment deviatie $\geqq$ in afleiding $V_{4} R$ is zeer hoog $(96 \%)$, terwijl de gevoeligheid $56 \%$ bedroeg.

Hoofdstuk 7 beschrijft de klinische waarde van ST-segment elevatie $\geq 1 \mathrm{~mm}$ in afleiding $V_{4} R$ tijdens het acute stadium van een onderwandinfarct. Bij patienten met ST-segment elevatie $\geqq 1 \mathrm{~mm}$ in afleiding $V_{4} R$ treden atrioventriculaire geleidingsstoornissen beduidend vaker op dan bij die groep van patienten waarbij deze ST-segment elevatie in $V_{4} R$ miet wordt gezien.

In hoofdstuk 8 worden de verschillen in rechter en linker ventrikel ejectiefractie bij patienten met een acuut onderwandinfarct met of zondler ST-segment elevatie $\geq 1$ 
$m m$ in $V_{4} R$ beschreven. Het wel of niet aanwezig zijn van ST-segment elevatie in $V_{4} R$ beinwloedt de linker ventrikel ejectiefractie niet. Wel werd een significante lagere ejectiefractie van de rechter ventrikel gevonden bij die patienten, waarbij een STsegment elevatie in $V_{4} R$ was gevonden tijdens het acute stadium van het hartinfarct.

\section{Curriculum vitae}

Simon Hubertus Joseph Gerardus Braat was born on March 17, 1948 in Roosendaal, The Netherlands. He graduated from high school St. Norbertus Lyceum, Roosendaal in 1966. In 1967 he went to Medical School at the Free University of Amsterdam and graduated in March 1974. From May 1974 till July 1975 he served. Her Majesty Queen Juliana of The Netherlands in military service. In August 1975 he started his residency in Internal Medicine at the Department of Internal Medicine of het Grootziekengasthuis in 's Hertogenbosch (Head Dr.J.B. Lips). In November 1977 he began his cardiologic training at the Department of Cardiology at St. Annadal Hospital in Maastricht under supervision of Prof. Dr. H.J.J. Wellens. From January 1980 till July 1980 he worked as a research fellow in Nuclear Cardiology at the Department of Cardiology at the Yale University, New Haven, Connecticut, U.S.A. (Head: Prof. Barry Zaret).

In November 1980 he completed his cardiologic training and became a member of the Capaciteitsgroep of Cardiollogy of the University of Limburg with special interest in nuclear cardiology. 


\section{Acknowledgements}

Many people have supported me in the work which lead to this thesis and the associated publications. It is impossible to thank everyone in person, but I want to express special thanks to those without whom $\mathbb{I}$ could not have started this research.

Prof. Hein Wellens, your scientific and dynamic personality created the infrastructure of a Department of Cardiology that gave me the opportunity to spend 6 months at Yale University in Connecticut to learn the basic principles of nuclear cardiology and thereafter to use this knowledge to start scientific investigations. I am deeply grateful for your encouragement and guidance.

Prof. Frans Wackers, I shall always remember the hospitality of you and your wife Marianne. You provided me with every opportunity to make my stay in New Haven a fruitful one. Without the help of your family, not only I, but also my wife Anneke, my children Jeroen en Manon, could not have enjoyed the six months in New Haven as much as we did. After my return to Maastricht you were always available to give advice and your remarks undoubtedly added to the quality of this thesis. Prof. Meyler and Prof. Flendrig, I greatly appreciate your critical reading and advice.

Dr. Pedro Brugada, the encouragement you gave me to continue my work and the stimulating discussions were of great value to me.

Miep Schrooders, I thank you very much for your patience and skill in typing and changing the manuscript and taking care that I remained working on this thesis. Last but not least, I want to mention Anneke, Jeroen and Manon for their endurance and understanding allowing me to continue my study. Maybe we can soon make up for this. 